KS. WALDEMAR W. ŻUREK SDB* - LUBLIN

\title{
GENEZA PARAFII RZYMSKO-KATOLICKIEJ PW. MATKI BOŻEJ KRÓLOWEJ KORONY POLSKIEJ W BARANOWICZACH
}

Pierwsza wzmianka o Baranowiczach datuje się przed 1706 rokiem, kiedy mieszkańcy tej małej wioski stawiali opór szwedzkim najeźdźcom ${ }^{1}$. W listopadzie 1871 roku na nowo wybudowanej stacji kolejowej kolei Moskiewsko-Brzeskiej (zwanej od imienia cara Aleksandrowską) został odprawiony pierwszy pociąg towarowo-pasażerski ze Smoleńska, który rozpoczął regularne kursowanie pociągów na dopiero co ukończonym odcinku Smoleńsk - Brześć. Sąsiednia stacja otrzymała nazwę Baranowicze, od położonej w pobliżu wsi o tej samej nazwie, która w krótkim czasie dała początek rozwojowi miasta. Datę tę uznaje się za moment powstania miasta. W 1882 roku Słownik geograficzny Królestwa Polskiego podawał: „Baranowicze wieś w pow. nowogródzkim, mieszkańców 150. O wiorstę ode wsi leży stacja Baranowicze drogi żelaznej brzesko-moskiewskiej, między Leśną a Pogorzelcami, o 188 wiorst od Brześcia”. Wokół stacji osiedliło się początkowo kilka rodzin pracowników kolei. Gdy naprzeciw budynku stacji zamieszkali w drewnianym domu hrabiostwo Rozwadowscy (żona prawosławna, mąż katolik), była tu już mała osada. Kiedy dwa lata później doprowadzono następną trasę kolejową Wilno-Łuniniec-Pińsk, pojawiła się druga stacja kolejowa Baranowicze Poleskie, w odległości 2,5 km od dotychczasowej stacji Baranowicze. Hrabia Jan Rozwadowski, właściciel osady od 1880 roku, dnia 27 V 1884 roku uzyskał dla Baranowicz Poleskich status miasteczka, które otrzymało nazwę Rozwadowo. Powstanie w rejonie Baranowicz ważnego węzła kolejowego spowodowało, że równolegle rozwijały się dwie, początkowo niezależne osady: Baranowicze i Rozwadowo.

$\mathrm{Na}$ gruntach wyprzedawanych pospiesznie przez mieszkańców okolicznych wiosek formowały się Baranowicze Poleskie. Hrabia Jan Rozwadowski przygo-

* Ks. Waldemar Witold Żurek SDB - dr hab. historii Kościoła, prof. KUL, dyrektor Ośrodka Archiwów Bibliotek i Muzeów Kościelnych, e-mail: zurek@kul.pl

${ }^{1}$ Według opisu wojny północnej (1700-1721) w książce o życiu szwedzkiego króla Karola XII autorstwa Görana Nordberga, Historia Karola XII, wydanej w Hamburgu w latach 1745-1751. 
tował plan rozbudowy swojej miejscowości, którą później nazwano Baranowiczami Centralnymi. Przybywali tu osadnicy, głównie Żydzi, którzy rozbudowywali osadę Rozwadowo. W miejsce drewnianego dworca w Baranowiczach Poleskich wzniesiono w 1899 roku ceglany budynek dworca pasażerskiego. W 1897 roku mieszkało tu 5.135 osób, nie licząc wojskowych, z czego połowę stanowili Żydzi. W 1914 roku było już ponad 31 tysięcy mieszkańców, a Baranowicze Poleskie stały się czwartym co do wielkości, miastem guberni mińskiej.

W latach 1918-1921 do odrodzonej Polski wróciło ze Wschodu ponad $2 \mathrm{mln}$ Polaków, z których większość przechodziła przez jeden z punktów repatriacyjnych JUR (Urząd ds. Powrotu Jeńców, Uchodźców i Robotników) umiejscowiony w Baranowiczach. $Z$ tysięcy ludzi przejeżdżających przez miasto, część decydowała się w nim osiedlić. Były to lata intensywnego rozwoju miasta, które w szybkim czasie stało się dominującym ośrodkiem przemysłowo-handlowym w województwie nowogródzkim, nazywanym Mała Warszawa, a nawet Polskim Chicago na Wschodzie. W 1919 roku Baranowicze otrzymały prawa miejskie, a w latach międzywojnia były ważnym ośrodkiem gospodarczym II Rzeczypospolitej i największym miastem województwa nowogródzkiego ${ }^{2}$.

$$
* * *
$$

W wielokulturowym mieście Baranowicze pierwsze cerkwie i synagogi powstały jeszcze za czasów carskich. Jednak władze rosyjskie konsekwentnie nie pozwalały na budowę kościołów. Niewielką kaplicę (a właściwie grobowiec rodzinny w kształcie kaplicy) wybudował hr. Rozwadowski po śmierci swojej żony. Co pewien czas odprawiana była w niej msza św. przez księdza z Nowej Myszy. Dopiero w 1920 roku miejscowa społeczność katolicka zainicjowała zbiórkę pieniężną na budowę świątyni. Najpierw jednak w centrum Baranowicz postawiono murowany sobór, do którego przeniesiono później mozaikę z rozbieranego w Warszawie (1926-1927) soboru Aleksandra Newskiego³. Drewniany kościół

${ }^{2}$ Wg danych JUR, od końca listopada 1918 roku do końca czerwca 1922 roku do Polski przybyło ponad $4 \mathrm{mln}$ osób. Polacy stanowili z tego ponad $2 \mathrm{mln}$, a reszta to jeńcy i uciekinierzy wojenni przemieszczający się przez nasz kraj tranzytem. D. Zagacki, Baranowicze, „Echo Polesia” 1 (25) 2010, s. 21-27.

${ }^{3}$ Latem 1894 roku rozpoczęto budowę na Placu Saskim w Warszawie soboru św. Aleksandra Newskiego, dla prawosławnych mieszkanców stolicy których liczba wynosiła ok. 43.000. Od 1900 roku rozpoczęto prace wykończeniowe i wystrój świątyni z 70 metrową wieżą, najwyższym obiektem budowlanym Warszawy. Dnia 20 V 1912 roku sobór został poświęcony. Po ewakuacji w 1915 roku rosyjskiej administracji i prawosławnych duchownych z Warszawy, sobór został przemianowany na garnizonowy kościół katolicki św. Henryka. W trzy miesiące po odzyskaniu przez Polskę niepodległości, warszawski magistrat podjął decyzję o likwidacji w mieście prawosławnych świątyń, z wyjątkiem dwóch, istniejących do dziś - cmentarnej na Woli i parafialnej na Pradze. Propozycje przeznaczenia soboru na budynek użyteczności publicznej (muzeum) nie zostały uwzględnione. Niektóre części wyposażenia soboru przeznaczono do innych świątyń. W ten sposób do budowanej (do 1931 roku) w Baranowiczach prawosławnej świątyni Pokrowy Bogarodzicy została przewieziona z soboru warszawskiego część mozaiki Koszelowa Spas z budowniczymi, przedstawiającej archi- 
parafialny pw. Podwyższenia Krzyża Świętego ${ }^{4}$ (przy ul. Narutowicza 78), wybudowany został w 1925 roku, gdy po zakończeniu wojny polsko-bolszewickiej, na mocy traktatu ryskiego Baranowicze powróciły do Polski.

W mieście dla potrzeb wojskowych i ich rodzin służył kościół garnizonowy pw. św. Antoniego Padewskiego w koszarach im. Tadeusza Kościuszki ${ }^{5}$. Generał broni i komendant garnizonu w Baranowiczach ${ }^{6}$ - Olgierd Pożerski ${ }^{7}$ bywając na

tekta soboru Leontija Benoisa trzymającego model soboru, a także nieduży fragment kompozycji Wasniecowa O Tiebie radujetsa, Błagodatnaja, wsiakaja twar.

${ }^{4}$ Wybudowany w 1925 roku sumptem parafian, za staraniem proboszcza ks. Lucjana Żołądkowskiego i w tymże roku poświęcony dnia 18 października przez bpa pińskiego Zygmunta Łozińskiego. Jego położenie na peryferiach miasta, w znacznej odległości od koszar i mieszkań kolejowych stwarzało problemy dla tamtejszych wiernych korzystających z tego kościoła. Spis kościołów i duchowieństwa diecezji pińskiej w R. P. 1939, Pińsk 1939, s. 49.

${ }^{5}$ Koszary wojskowe im. T. Kościuszki zlokalizowane były obok linii kolejowej, naprzeciw dworca Baranowicze Poleskie. Zostały zbudowane pod koniec XIX wieku dla żołnierzy rosyjskich wojsk kolejowych w których służyli także Polacy. Służba w wojsku carskim mogła być krótka (kilka lat - dla osób lepiej wykształconych) lub długa (25 lat). W skład carskich wojsk inżynieryjnych wchodziło 7 batalionów kolejowych. Żołnierze z tych batalionów pracowali przy budowie innych kolei żelaznych: moskiewsko-brzeskiej i poleskiej, które krzyżowały się w Baranowiczach. Bataliony kolejowe zostały jako pierwsze skoszarowane w pobliżu nowo powstałego dworca.

Budynki koszarowe w Baranowiczach służyły początkowo jako punkt repatriacyjny dla uchodźców, wracających do Polski po pierwszej wojnie światowej. Dopiero po likwidacji punktu w 1923 roku, do koszar wprowadzono 78 Pułk Piechoty, 26 Pułk Ułanów im. hetmana Jana Karola Chodkiewicza, 9 Dywizjon Artylerii Konnej oraz dowództwo Nowogródzkiej Brygady Kawalerii, w której służył w 1937 roku Władysław Anders. Baranowicze były najbardziej na wschód wysuniętym garnizonem w II RP. Zagacki, Baranowicze, s. 27.

${ }^{6}$ Garnizon - to stałe miejsce stacjonowania danej jednostki wojskowej w czasie pokoju. Funkcje garnizonu pełnią najczęściej miasta, miasteczka, forty, zamki, czy osady. Miasto garnizonowe to powszechne określenie miasta, w którym wybudowano koszary. Na mocy pokoju ryskiego z 1921 roku Baranowicze znalazły się w granicach Polski. Ponieważ jednak ZSRR nie pogodził się z niepodległością Polski, granice wschodnie wymagały wzmożonej ochrony, tym bardziej, że często ją naruszano. Dla uszczelnienia granicy z Sowietami i ochrony obywateli, utworzony został Korpus Ochrony Pogranicza (KOP). Od tej pory: Garnizon Baranowicze został podporządkowany dowództwu Korpusu Okręgu Brześć nad Bugiem. H. Dominiczak, Granica wschodnia Rzeczypospolitej Polskiej w latach 1919-1939, Warszawa 1992, s. 102-128.

${ }^{7}$ Pożerski Olgierd (1880-1930) - pułkownik artylerii Armii Imperium Rosyjskiego, generał brygady Wojska Polskiego. Od 1901 roku był oficerem zawodowym rosyjskiej artylerii. Uczestniczył w wojnie rosyjsko-japońskiej 1904-1905 i walczył na froncie niemieckim w czasie pierwszej wojny światowej. Od listopada 1918 roku pełnił służbę w Wojsku Polskim i mianowany został dowódcą Twierdzy Zegrzei. W maju 1919 roku objął dowództwo 8 Brygady Artylerii, czasowo XVI Brygady Piechoty. W 1920 roku kolejno pełnił funkcje dowódcy artylerii Grupy Operacyjnej gen. Józefa Lasockiego, dowódcy 8 Dywizji Piechoty, dowódcy artylerii Grupy Operacyjnej pułkownika Stanisława Burhardta-Bukackiego. W bitwie o Warszawę, w sierpniu 1920 roku był dowódcą artylerii odcinka Ząbki, dowódcą 8 Dywizji Piechoty (sierpień 1920 - styczeń 1921), szefem artylerii i uzbrojenia ( od stycznia 1921 - wrzesień 1924). Dnia 31 III 1924 roku prezydent RP, Stanisław Wojciechowski awansował go na generała brygady. We wrześniu 1924 roku objął dowództwo 18 Dywizji Piechoty w Łomży, a od lipca 1925 roku objął dowództwo Obszaru Warownego „Wilno”. W październiku 1926 roku został przeniesiony na stanowisko dowódcy 20 Dywizji Piechoty w Ba- 
nabożeństwach w tym kościele zauważył, że oprócz wojskowych znaczny procent gromadzących się tam wiernych stanowiła ludność cywilna. Z tego faktu wnioskował, że w mieście odczuwa się brak świątyni parafialnej. Dotychczasowy niewielki kościół parafialny pw. Podwyższenia Krzyża Świętego, wybudowany na obrzeżach miasta był niewystarczający dla potrzeb rozbudowujących się Baranowicz. Ludność katolicką w mieście szacowano wówczas na siedem tysięcy mieszkańców oraz około trzy tysiące osób wojskowych, którym niewielki parafialny kościół garnizonowy pw. św. Antoniego Padewskiego, będący raczej kaplicą, nie wystarczał w dostatecznym stopniu. W związku z powyższym gen. Olgierd Pożerski doszedł do przekonania, że budowa kolejnego kościoła parafialnego w Baranowiczach stała się pilną sprawą, tym bardziej, że liczba mieszkańców miasta z roku na rok wzrastała.

Po odbyciu szeregu narad z przedstawicielami miejscowego społeczeństwa, gen. O. Pożerski zwrócił się osobiście do marszałka Józefa Piłsudskiego z prośbą o poparcie budowy nowej świątyni. Po wysłuchaniu jego relacji marszałek przyrzekł ze swej strony wsparcie na rzecz budowy kościoła, jednak zaznaczył, że wsparcie finansowe rządu polskiego na budowę kościoła garnizonowego lub kościoła parafialnego, nie ma widoków powodzenia. Sugerował zainicjowanie budowy kościoła „ogólnego” - zarówno dla ludności cywilnej jak i dla wojska. $\mathrm{Na}$ taką inwestycję marszałek widział możliwość udzielenia rządowego kredytu. Zalecał ponadto utworzenie specjalnego Komitetu Społecznego Budowy, złożonego z przedstawicieli miejscowego społeczeństwa, którego zadaniem miało być gromadzenie funduszy na planowaną inwestycję i czynienie starań o uzyskanie ewentualnych zapomóg rządowych. Zachęcony sugestią marszałka Piłsudskiego, komendant garnizonu dnia 5 XII 1928 roku zainicjował w kasynie oficerskim 78 Pułku Piechoty ${ }^{8}$ zebranie w sprawie budowy kościoła w Baranowiczach. Wzięli w nim udział przedstawiciele władz administracyjnych, samorządowych, duchowieństwa, społeczeństwa i garnizonu wojskowego miasta Baranowicz. Zebrali się w tym dniu: gen. Olgierd Pożerski, płk Stanisław Skotnicki, płk Mieczysław Boruta-Spiechowicz, płk Władysław Dąbrowski, płk Wacław Szalewicz, płk Mieczysław Sokół-Szahin, mjr Bronisław Bednarczyk, mjr Roman Gutkowski, kpt. Stanisław Wojciechowski, kpt. Wojniłowicz, proboszcz parafii Podwyższenia Świętego Krzyża i dziekan baranowicki - ks. Lucjan Żołądkowski ${ }^{9}$, proboszcz

ranowiczach. Zmarł w obozie ćwiczeń w Leśnej koło Baranowicz. Pośmiertnie awansowany został do stopnia generała dywizji. Pochowany został w Wilnie na Cmentarzu Benedyktyńskim. Był autorem studiów wojskowo-historycznych z zakresu taktyki artylerii. P. Stawecki, Stownik biograficzny generałów Wojska Polskiego 1918-1939, Warszawa 1994, s. 260-261.

878 Słucki Pułk Piechoty - sformowany został w Baranowiczach na przełomie lat 1919/1920. Pułk ten, będąc w 1920 roku w składzie 2 Dywizji Piechoty Litewsko-Białoruskiej stoczył w dniu 26 VII 1920 roku ciężki bój pod Kuźnicą. Dlatego też dzień 26 lipca ogłoszono świętem pułku. Sztandar wręczony pułkowi dnia 1 VI 1923 roku przez generała Lucjana Żeligowskiego ufundowało miasto Baranowicze i ziemia baranowicka.

${ }^{9}$ Ks. Żołądkowski Lucjan (1883-1946) - kapłan diecezji mińskiej, następnie pińskiej. Święcenia kapłańskie przyjął 25 I 1909 roku w Petersburgu. Pracował od 1910 roku jako wikariusz w Mińsku (Złota Górka), od 1911 roku jako administrator parafii przy kościele pw. św. Szymona i Heleny 
parafii wojskowej św. Antoniego Padewskiego - ks. mjr Franciszek Walasek, dyrektor Karol Pieniążkiewicz, dyrektor W. Pietrkiewicz, dyrektor W. Terajewicz, sędzia J. Bylica, starosta powiatu baranowickiego Jan Emeryk, burmistrz miasta Eugeniusz Dembiński-Pióro (Piuro), inż. T. Żołądkowski, inż. Marian Prawdzic -Layman, M. Apanasiewiczowa, Józef Bukowski, Stanisław Gniazdowski, Kramarczyk, A. Szalewiczowa, Józef Szulc, inspektor szkolny Jan Wójtowicz ${ }^{10}$.

$\mathrm{Na}$ zwołanym zebraniu, jego inicjator zapoznał zgromadzonych z potrzebą utworzenia $\mathrm{w}$ mieście kolejnego ośrodka duszpasterskiego, a w związku z tym i budowy nowego kościoła. Zaproponował zebranym wybór przewodniczącego zebrania i sekretarza. Przewodniczącym zebrania wybrano jednogłośnie gen. Olgierda Pożerskiego a sekretarzem został burmistrz Eugeniusz Dembiński-Pióro. Kolejnym zadaniem zebranych było powzięcie uchwały w sprawie budowy kościoła i wybór Komitetu Wykonawczego ${ }^{11}$. Podjęta na tym zebraniu uchwała brzmiała:

My, niżej podpisani przedstawiciele władz: administracyjnej i samorządowej, społeczeństwa miasta Baranowicze oraz tutejszego garnizonu wojskowego, postanawiamy na zebraniu w dniu 5 XII 1928 roku rozpocząć dzieło budowy kościoła rzymsko-katolickiego dla potrzeb żołnierzy, pracowników kolejowych i miejscowej ludności miasta Baranowicz ${ }^{12}$.

W dalszej części obrad zebrani uzasadniali, że zarówno peryferyjny kościół parafialny pw. Podwyższenia Świętego Krzyża jak i kaplica wojskowa pw. św. Antoniego Padewskiego, mieszcząca się w drewnianym baraku, są niewystarcza-

w Mińsku, w latach 1923-1933 był proboszczem parafii pw. Podwyż szenia Krzyża Świętego w Baranowiczach i dziekanem baranowickim. Wybudował kościół pw. Podwyższenia Krzyża Świętego (1925) w Baranowiczach i inicjował budowę kościoła pw. Matki Bożej Królowej Korony Polskiej w tym mieście. W latach 1933-1937 pełnił obowiązki proboszcza parafii pw. Najświętszego Serca Pana Jezusa w Brześciu na Grajewskim Przedmieściu (ul. Mieszczańska) i dziekana brzeskiego oraz rektora kościoła filialnego w Skokach. W latach 1937-1938 był dziekanem i proboszczem kościoła Podwyższenia Krzyża Świętego w Brześciu nad Bugiem. Od 1938 roku został kierownikiem Wydziału Metrykalnego Kurii Biskupiej w Pińsku. W 1940 roku zastępował przebywającego na leczeniu sanatoryjnym proboszcza z Peliszcz (dekanat i obwód brzeski), ks. Wacława Tumiłowicza i ostatecznie pozostał tam na stałe, także po drugiej wojnie światowej. Obsługiwał także parafię kamieniecką. Zmarł na raka w Brześciu i tam został pochowany na cmentarzu katolickim przy ul. 3 Maja (po wojnie Puszkińska) przy neoklasycznej kaplicy. Elenchus ecclesiarum et cleri saecularis ac regularis dioecesis minscensis pro Anno Domini 1924, Mińsk 1924, s. 20-21, 47; E. Borowski, Noty biograficzne o zmarlych kapłanach, Drohiczyn [b. r. wyd.], s. 161, mps w ADD; K. Wojciechowski, Cmentarz katolicki w Brześciu, „Niedziela” nr 45 (737) z 4 XI 2012, s. 7.

${ }^{10}$ Archiwum Diecezjalne w Drohiczynie (dalej: ADD), Zespół Archiwum Parafii Baranowicze, Sygn. III/W, Protokół zebrania inauguracyjnego z 5 XII 1928 roku w sprawie budowy kościoła rzymskokatolickiego w Baranowiczach.

${ }^{11}$ W skład Komitetu Wykonawczego winni wejść przedstawiciele: wojska w osobie komendanta, władz administracyjnych - w osobie starosty Baranowicz, władz samorządowych - w osobie burmistrza, proboszcz parafii rzymskokatolickiej w Baranowiczach, proboszcz parafii wojskowej i przedstawiciel władz kolejowych.

${ }^{12}$ W 1928 roku ludność katolicka Baranowicz wynosiła 4.000 osób, pracowników kolejowych i wojskowych z rodzinami. 
jące dla tamtejszych katolików mundurowych i cywilnych mieszkańców miasta. Nie mówiąc już o Nowych Baranowiczach, których ludność w zupełności była pozbawiona świątyni parafialnej. W powziętej uchwale podkreślono, że za budową kościoła przemawiały także względy państwowe. Mieszkająca katolicka ludność polska, zarówno miasta jak i okolicy, będąca większością wśród innych wyznań, często wrogo usposobionych do Państwa polskiego, powinna mieć kościół murowany, odpowiednich rozmiarów, odpowiadający i wystarczający jej potrzebom duchowym. Wznoszona w tym czasie murowana cerkiew prawosławna, dla tamtejszych wiernych będących mniejszością w stosunku do katolików, budowana była przy pomocy subsydiów rządowych. Końcowy zapis uchwały polecał Komitetowi Wykonawczemu zwrócenie się do prezesa Rady Ministrów z prośbą o wsparcie finansowe powyższej inicjatywy budowlanej, niezależnie od funduszów osiągniętych drogą składek od miejscowego społeczeństwa, które nie będzie W stanie samodzielnie zrealizować tego przedsięwzięcia ${ }^{13}$.

W końcowej części zabrania wyłoniono Komitet Wykonawczy Budowy Kościoła do którego powołano:

1. Przedstawiciela wojska - komendanta garnizonu - generała broni Olgierda Pożerskiego,

2. Przedstawiciela władzy administracyjnej - starostę baranowickiego - Jana Emeryka,

3. Przedstawiciela władzy samorządowej - burmistrza Baranowicz - Eugeniusza Dembińskiego-Pióro,

4. Proboszcza parafii i dziekana baranowickiego - ks. Lucjana Żołądkowskiego,

5. Proboszcza parafii wojskowej - ks. majora Franciszka Walaska,

6. Przedstawiciela władz kolejowych - inżyniera Mariana Prawdzic-Leymana.

W powziętej uchwale sformułowano także sprawę zarządu projektowanego kościoła. Jednogłośnie zgodzono się, że będzie to kościół parafialny z którego będą korzystali także wojskowi. Miało to być szczegółowo określone w specjalnym statucie, który winien otrzymać zatwierdzenie władz kościelnych, wojskowych i cywilnych. Planowano także wybudowanie plebanii dla proboszcza wojskowego. Zebrani upoważnili przewodniczącego i sekretarza zebrania, aby tak powziętą uchwałę przedłożył właściwym władzom ${ }^{14}$.

Na kolejne zebranie Komitetu Wykonawczego w kasynie wojskowym dnia 27 XII 1928 roku przybyło 29 osób. Jego przewodniczący zrelacjonował wizytę delegatów Komitetu Wykonawczego ${ }^{15}$ w Warszawie w sprawie uzyskania subsydiów na budowę kościoła. W czasie tej wizyty delegacja została przyjęta przez premiera rządu - prof. Kazimierza Bartla, który już uprzednio zapoznał się z tym tematem

\footnotetext{
${ }^{13} \mathrm{~W}$ przedłożonej uchwale Komitet winien prosić prezesa Rady Ministrów o wstawienie do budżetu na rok 1930/1931 pewnej sumy na budowę kościoła oraz o udzielenie już w 1929 roku subsydium na rozpoczęcie budowy. ADD, Zespół Archiwum Parafii Baranowicze, Sygn. III/W, Uchwała Komitetu Wykonawczego budowy kościoła z 5 XII 1928 roku.

${ }^{14}$ Tamże.

${ }^{15} \mathrm{~W}$ delegacji wzięli udział: gen. Olgierd Pożerski, starosta powiatu baranowickiego Jan Emeryk i płk Stanisław Grzmot-Skotnicki. ADD, Zespół Archiwum Parafii Baranowicze, Sygn. III/W, Protokół zebrania z 27 XII 1928 roku.
} 
od samego marszałka Piłsudskiego i zapewnił delegatów o poparciu poczynań Komitetu Wykonawczego Budowy Kościoła. Nadmienił przy tej okazji, że na budowę kościoła asygnowano już 13.000 złotych na koszty związane ze sporządzeniem planu i kosztorysu budowy. Jednocześnie zalecił ogłoszenie konkursu na wykonanie projektu świątyni, poprzez zwrócenie się do Zrzeszenia Architektów Polskich ${ }^{16}$ w Warszawie. Na zakończenie wizyty w kancelarii premiera gen. Olgierd Pożerski oświadczył, że konkurs na budowę kościoła już został ogłoszony ${ }^{17}$.

$\mathrm{Na}$ wspomnianym zebraniu podjęto uchwałę o nadaniu wezwania przyszłemu kościołowi w Baranowiczach - Matki Bożej Królowej Korony Polskiej. Następnie uchwalono i przyjęto statut Komitetu Wykonawczego Budowy Kościoła, który został zapisany w 14 paragrafach ${ }^{18}$. Otrzymał on dnia 28 II 1929 roku zatwierdzenie Urzędu Wojewódzkiego w Nowogródku ${ }^{19}$. W myśl paragrafu 9 statutu, Komitet wyłania spośród siebie na czas nieograniczony ścisły Komitet Wykonawczy, składający się z prezesa, dwóch zastępców, skarbnika i sekretarza. W myśl par. 14 statutu Komitetu, powołano komisję rewizyjną ${ }^{20}$ oraz określono wysokość składki członkowskiej na 6 złotych rocznie.

W skład powołanego Komitetu Wykonawczego, który uzyskał osobowość prawną i dysponował własną okrągłą pieczęcią, weszli jako pierwsi członkowie: gen. Olgierd Pożerski, starosta powiatu baranowickiego Jan Emeryk, burmistrz Eugeniusz Dembiński-Pióro, inż. Marian Prawdzic-Leyman, proboszcz i dziekan baranowicki - ks. Lucjan Żołądkowski, proboszcz parafii wojskowej - ks. Franciszek Walasek. Ponadto jego członkami mógł zostać każdy obywatel Rzeczypospolitej Polskiej zaproszony przez Komitet. Na wniosek gen. Pożerskiego Komitet postanowił zaprosić na honorowych członków Komitetu Wykonawczego kościoła w Baranowiczach: marszałka Józefa Piłsudskiego, prezesa Rady Ministrów prof. Kazimierza Bartla, wojewodę nowogródzkiego Zygmunta Beczkowicza, dowód-

${ }^{16}$ W Warszawie działało Stowarzyszenie Architektów Polskich, założone w 1926 roku. W Katowicach - Związek Architektów na Śląsku, założone w 1925 roku. W 1934 wszystkie działające w Polsce stowarzyszenia regionalne architektów zjednoczyły się w Stowarzyszenie Architektów Rzeczypospolitej Polskiej (SARP).

${ }^{17}$ ADD, Zespół Archiwum Parafii Baranowicze, Sygn. III/W, Protokół zebrania z 27 XII 1928 roku.

${ }^{18}$ Poszczególne tytuły statutu: 1. Nazwa, 2. Cel, 3. Siedziba, 4. Sposób działania, 5. Organizatorzy Komitetu, 6. Członkowie, 7. Osobowość prawna, 8. Obowiązki członków, 9. Komitet Wykonawczy, 10. Zgromadzenia, 11. Zakres spraw, 12. Fundusze, 13. Rachunkowość, 14. Komisja Rewizyjna. ADD, Zespół Archiwum Parafii Baranowicze, Sygn. III/W, Protokół zebrania w dniu 27 XII 1928 roku.

${ }^{19}$ ADD, Zespół Archiwum Parafii Baranowicze, Sygn. III/W, Protokół zebrania z 15 IV 1934 roku, s. 1.

${ }^{20}$ Członkami komisji rewizyjnej w 1928 roku zostali: płk. Mieczysław Sokół-Szachin, zawiadowca stacji Kwiatkowski, Józef Szulc. Na ich zastępców: płk. Wacław Szalewicz, inspektor szkolny - Jan Wójtowicz, kierownik Kasy Chorych - Stanisław Gniazdowski. Natomiast w kwietniu 1934 roku komisję rewizyjną stanowili: ppłk. Mieczysław Sokół-Szachin, mjr Goebel, p. Czyżewski; ADD, Zespół Archiwum Parafii Baranowicze, Sygn. III/W, Protokół zebrania w dniu 27 XII 1928, 14 IV 1934 roku. 
cę Okręgu Korpusu IX ${ }^{21}$ gen. Mieczysława Rysia-Trojanowskiego, arcybiskupa wileńskiego Romualda Jałbrzykowskiego, biskupa poleskiego Zygmunta Łozińskiego $^{22}$, biskupa polowego Wojska Polskiego Stanisława Galla.

Aby akcję budowy kościoła oprzeć na szerokich warstwach społeczeństwa, Komitet Wykonawczy postanowił powołać do życia „Komitet Obywatelski Budowy Kościoła pod wezwaniem Królowej Korony Polskiej” w Baranowiczach. W związku z powyższym w miejsce Komitetu Wykonawczego wybrano Komitet Obywatelski Budowy Kościoła. Odbyło się to na zebraniu Komitetu Wykonawczego dnia 28 III 1930 roku w lokalu Klubu Kresowego. Zaproszono na to zebranie przedstawicieli duchowieństwa, wojska, urzędów państwowych oraz wszelkich instytucji katolickich znajdujących się na terenie Baranowicz. Dotychczasowy przewodniczący Komitetu Wykonawczego gen. O. Pożerski zapoznał zebranych z historią Komitetu Wykonawczego, jego działaniami i dotychczasowymi osiągnięciami. Zabierając głos starosta powiatu baranowickiego Z. Prze-

${ }^{21} \mathrm{Na}$ mocy decyzji polskiego ministerstwa Spraw Wojskowych dnia 1 VIII 1921 roku utworzono Wojskowy Okręg Korpusu Brześć Litewski. W 1922 roku teren Polski został podzielony na dziesięć Okręgów Korpusów, a wśród nich Okręg Korpusu nr IX, nazywany Poleskim. Sztab korpusu stacjonował w Brześciu, który dnia 12 XI 1923 roku został przemianowany na Brześć nad Bugiem. Stacjonowały w nim: bataliony wchodzące w skład 20 Dywizji Piechoty, część batalionów 44 Pułk Strzelców Legii Amerykańskiej (sformowany w 1918 r. we Francji), sztab Brygady Kawalerii Baranowicze (1 IX 1937 przemianowaną w Nowogródzką Brygadę Kawalerii), 1 i 4 dywizjon 20 Pułk Artylerii Lekkiej. W skład Okręgu Korpusu wchodziły oddziały województwa białostockiego i nowogródzkiego, północnej części lubelskiego i dużej części województwa poleskiego.

Korpus Ochrony Pogranicza - formacja wojskowa przeznaczona dla ochrony wschodniej granicy Polski ze Związkiem Radzieckim, Litwą, Łotwą, częściowo z Rumunią i Prusami Wschodnimi, dla zapewnienia i ugruntowania bezpieczeństwa publicznego oraz zwalczania działalności antypaństwowej. Działał w pasie ok. 30 kilometrów od granicy. KOP prowadził również prace społecznogospodarcze i podejmował inicjatywy kulturalno-oświatowe. Od 1 IX 1939 roku podjął walkę z Niemcami, a od 17 września z Armią Czerwoną. W. Bieszanow, Twierdza Brzeska, Warszawa 2012, s. 117; M. Cieplewicz, Korpus Ochrony Pogranicza, w: Historia Drugiej Rzeczypospolitej, red. A. Garlicki, Warszawa 1999, s. 171; Dominiczak, Granica wschodnia Rzeczypospolitej Polskiej, s. 102-128.

${ }^{22}$ Bp Łoziński Zygmunt (1870-1932) - studia teologiczne ukończył w Petersburgu, święcenia kapłańskie przyjął w 1895 roku. Pracował jako wykładowca w seminarium i opiekun młodzieży akademickiej. W latach 1898-1900 skazany na banicję, przebywał w klasztorze karnym w Agłomie na Łotwie. Następnie pracował w duszpasterstwie: w Smoleńsku, Tule, Rydze, Kalwarii koło Mińska (proboszcz). Usunięty z Mińska za przyjmowanie unitów do Kościoła katolickiego, podjął wykłady w Akademii Duchownej Petersburgu i kontynuował studia biblijne (Monachium, Rzym, Jerozolima, Rzym). W czasie pierwszej wojny światowej był kapelanem w obozach jeńców wojennych. W 1917 roku został ordynariuszem reaktywowanej diecezji mińskiej. Sakrę biskupią przyjął w 1918 roku w Warszawie. Po wejściu w grudniu 1918 roku Armii Czerwonej do Mińska ukrywał się. Powrócił do miasta w sierpniu 1919 roku. Jeszcze w tym roku, po proklamowaniu Białoruskiej SRR, został aresztowany i więziony w Moskwie. Na mocy traktatu ryskiego 1921 roku został zwolniony. Udał się wówczas do Nowogródka, gdzie organizował życie religijne w polskiej części diecezji mińskiej. W 1925 roku został ordynariuszem utworzonej diecezji pińskiej. Zmarł w opinii świętości, jego proces beatyfikacyjny rozpoczęto w 1957 roku w Rzymie. J. Misiurek, Łoziński Zygmunt, w: Encyklopedia Katolicka (dalej: EK), t. 11, Lublin 2006, kol. 554-555. 
pałkowski oświadczył zebranym, że Komitet Wykonawczy wykonał znaczą część pracy przez uzyskanie funduszy na przeprowadzenie konkursu oraz zainteresował budową kościoła rząd. Obecne nadeszła potrzeba przenieść działalność Komitetu Wykonawczego na szerszy teren, w związku z tym na jego wniosek zebrani podjęli uchwałę: podziękować dotychczasowemu prezesowi gen. Pożerskiemu za przewodniczenie Komitetowi Wykonawczemu, udzielić mu absolutorium i wybrać Komitet Obywatelski Budowy Kościoła w Baranowiczach. Po przeprowadzonych wyborach okazało się, że skład osobowy powołanego nowego już Komitetu Obywatelskiego Budowy Kościoła pozostał w zasadzie jak dotychczas, jedynie została zwiększona liczba jego członków ${ }^{23}$. Wybrano także komisję rewizyjną. W jej skład weszli: inspektor skarbowy Mathias, dyrektor Komunalnej Kasy Oszczędności - Terajewicz, major Goebela ${ }^{24}$.

Tab. 1. Komitet Budowy Kościoła w Baranowiczach 1928-1938.

\begin{tabular}{|c|c|c|c|c|c|}
\hline \multicolumn{6}{|c|}{ Komitet Wykonawczy } \\
\hline Lata & Prezes & Zastępcy & Skarbnik & Sekretarz & Członkowie \\
\hline 1 & 2 & 3 & 4 & 5 & 6 \\
\hline 1928- & O. Pożerski & $\begin{array}{l}\text { I. Jan Emeryk } \\
\text { II. ks. Lucjan } \\
\text { Żołądkowski }\end{array}$ & $\begin{array}{l}\text { S. Grzmot-Skot- } \\
\text { nicki }\end{array}$ & $\begin{array}{l}\text { E. Dembiński } \\
\text {-Pióro }\end{array}$ & $\begin{array}{l}\text { ks. F. Walasek } \\
\text { M. Prawdzic } \\
\text {-Leyman }\end{array}$ \\
\hline $\begin{array}{l}\text { od } 11 \\
\text { XI } \\
1929\end{array}$ & O. Pożerski & $\begin{array}{l}\text { I. J. Emeryk } \\
\text { II. ks. Lucjan } \\
\text { Żołądkowski }\end{array}$ & $\begin{array}{l}\text { M. Sokół-Sza- } \\
\text { hin (zastępstwo) }\end{array}$ & $\begin{array}{l}\text { E. Dembiński } \\
\text {-Pióro }\end{array}$ & $\begin{array}{l}\text { Z. Przepakłow- } \\
\text { ski } \\
\text { K. Mackiewicz }\end{array}$ \\
\hline
\end{tabular}

${ }^{23}$ Do Komitetu Obywatelskiego Budowy Kościoła w Baranowiczach zostali wybrani: generał Olgierd Pożerki - prezes, Jan Emeryk - pierwszy zastępca, ks. Lucjan Żołądkowski - drugi zastępca, kierownik Biura Wydziału Powiatowego A. Bruszkiewicz - sekretarz. Członkowie: naczelnik Kasy Skarbowej - A. Bieniasz-Krzywczyc, starosta powiatu baranowickiego - Z. Przepałkowski, burmistrz baranowicki - Stefan Sieńkowski, prezes Związku Ziemian - G. Górski, generał Stanisław Grzmot-Skotnicki, inżynier Marian Prawdzic-Layman, księża prefekci: Kazimierz Bohusz i Stanisław Karpowicz, Aleksandra Szalewicz i Helena Trojanowska. Po tragicznej śmierci gen. Pożerskiego dnia 30 VIII 1930 roku, przewodniczącego wybrano dopiero dnia 30 I 1931 roku, którym został starosta powiatu baranowickiego Z. Przepałkowski. Po jego odejściu z Komitetu Obywatelskiego, prezesem został generał Stanisław Grzmot-Skotnicki, wybrany dnia 14 XII 1931 roku. Z biegiem czasu, z powodu przeniesień służbowych następowała wymiana zarządu i innych członków Komitetu Obywatelskiego. ADD, Zespół Archiwum Parafii Baranowicze, Sygn. III/W, Protokół zebrania z 28 III 1930, 15 IV 1934 roku.

${ }^{24}$ ADD, Zespół Archiwum Parafii Baranowicze, Sygn. III/W, Protokół zebrania z 28 III 1930 (L. 227/30), 31 I 1932 roku. 


\begin{tabular}{|c|c|c|c|c|c|}
\hline 1 & 2 & 3 & 4 & 5 & 6 \\
\hline $\begin{array}{l}\text { od } \\
20 \text { III } \\
1930\end{array}$ & O. Pożerski & $\begin{array}{l}\text { I. Jan Emeryk } \\
\text { II. ks. Lucjan } \\
\text { Żołądkowski }\end{array}$ & $\begin{array}{l}\text { M. Sokół-Sza- } \\
\text { hin (zastępstwo) }\end{array}$ & A. Bruszkiewicz & $\begin{array}{l}\text { ks. F. Walasek } \\
\text { Z. Przepałkow- } \\
\text { ski } \\
\text { S. Grzmot-Skot- } \\
\text { nicki } \\
\text { M. Prawdzic } \\
\text {-Leyman } \\
\text { E. Dembiński } \\
\text {-Pióro }\end{array}$ \\
\hline \multicolumn{6}{|c|}{ Komitet Obywatelski } \\
\hline $\begin{array}{l}\text { od } \\
28 \text { III } \\
1930\end{array}$ & O. Pożerski & $\begin{array}{l}\text { I. Jan Emeryk } \\
\text { II. ks. Lucjan } \\
\text { Żołądkowski }\end{array}$ & & A. Bruszkiewicz & $\begin{array}{l}\text { A. Bieniasz } \\
\text {-Krzywczyc } \\
\text { Z. Przepałkow- } \\
\text { ski } \\
\text { S. Sieńkowski } \\
\text { M. Prawdzic } \\
\text {-Layman } \\
\text { S. Grzmot-Skot- } \\
\text { nicki } \\
\text { G. Górski } \\
\text { A. Szalewicz } \\
\text { H. Trojanowska } \\
\text { ks. K. Bohusz } \\
\text { ks. S. Karpo- } \\
\text { wicz } \\
\text { A. Bruszkiewicz }\end{array}$ \\
\hline $\begin{array}{l}30 \mathrm{I} \\
1931\end{array}$ & $\begin{array}{l}\text { Z. Przepałkow- } \\
\text { ski }\end{array}$ & $\begin{array}{l}\text { ks. Franciszek } \\
\text { Walasek }\end{array}$ & $\begin{array}{l}\text { A. Bieniarz } \\
\text {-Krzywczyc }\end{array}$ & A. Bruszkiewicz & $\begin{array}{l}\text { ks. L. Żołąd- } \\
\text { kowski } \\
\text { S. Grzmot-Skot- } \\
\text { nicki } \\
\text { A. Bieniarz } \\
\text {-Krzywczyc } \\
\text { M. Prawdzic } \\
\text {-Layman } \\
\text { A. Szalewicz } \\
\text { H. Trojanowska } \\
\text { A. Bruszkiewicz }\end{array}$ \\
\hline $\begin{array}{l}14 \\
\text { XII } \\
1931\end{array}$ & $\begin{array}{l}\text { S. Grzmot-Skot- } \\
\text { nicki }\end{array}$ & $\begin{array}{l}\begin{array}{l}\text { I. ks. Antoni } \\
\text { Aleksandro- } \\
\text { wicz }^{\mathrm{a}}\end{array} \\
\text { II. M. Sokół- } \\
\text { Szahin }\end{array}$ & $\begin{array}{l}\text { A. Bieniarz } \\
\text {-Krzywczyc }\end{array}$ & A. Bruszkiewicz & $\begin{array}{l}\text { ks. L. Żołąd- } \\
\text { kowski } \\
\text { M. Prawdzic } \\
\text {-Layman } \\
\text { A. Szalewiczo- } \\
\text { wa } \\
\text { H. Trojanowska } \\
\text { A. Bruszkiewicz }\end{array}$ \\
\hline
\end{tabular}

${ }^{a}$ Ks. Aleksandrowicz Antoni (1893-1940) - święcenia kapłańskie otrzymał w 1916 r. w Petersburgu. Pracował jako katecheta w Mińsku, od 1919 r. w korpusie duszpasterskim Wojska Polskiego, następnie był kapelanem przy duszpasterstwie rzymskokatolickim 4 armii. W 1928 r. został proboszczem parafii wojskowej Słonim, a następnie administratorem parafii wojskowej w Baranowiczach. We wrześniu 1939 r. był ranny, więziony w Kozielsku, zamordowany został przez NKWD. E. Borowski, Martyrologium duchowieństwa diecezji pińskiej w latach 1939-1956, w: Martyrologium duchowieństwa polskiego 1936-1956, Łódź, s. 113. 


\begin{tabular}{|c|c|c|c|c|c|}
\hline 1 & 2 & 3 & 4 & 5 & 6 \\
\hline $\begin{array}{l}18 \mathrm{I} \\
1932\end{array}$ & $\begin{array}{l}\text { S. Grzmot-Skot- } \\
\text { nicki }\end{array}$ & $\begin{array}{l}\text { I. ks. Antoni } \\
\text { Aleksandrowicz } \\
\text { II. M. Sokół- } \\
\text { Szahin }\end{array}$ & $\begin{array}{l}\text { A. Bieniarz } \\
\text {-Krzywczyc }\end{array}$ & A. Bruszkiewicz & $\begin{array}{l}\text { ks. L. Żołąd- } \\
\text { kowski } \\
\text { M. Prawdzic } \\
\text {-Layman } \\
\text { A. Szalewicz } \\
\text { H. Trojanowska } \\
\text { T. Machalski } \\
\text { (od 18 I 1932) } \\
\text { - 26 Pułku } \\
\text { Ułanów } \\
\text { J. Neugebauer } \\
\text { (od 18 I 1932) } \\
\text { dowódca 29 } \\
\text { Pułku Ułanów }\end{array}$ \\
\hline $\begin{array}{l}20 \mathrm{~V} \\
1932\end{array}$ & $\begin{array}{l}\text { S. Grzmot-Skot- } \\
\text { nicki }\end{array}$ & $\begin{array}{l}\text { I. ks. Antoni } \\
\text { Aleksandrowicz } \\
\text { II. M. Sokół- } \\
\text { Szahin }\end{array}$ & $\begin{array}{l}\text { A. Bieniarz } \\
\text {-Krzywczyc }\end{array}$ & Ludwik Rau & $\begin{array}{l}\text { ks. L. Żołąd- } \\
\text { kowski } \\
\text { M. Prawdzic } \\
\text {-Layman } \\
\text { A. Szalewicz } \\
\text { H. Trojanowska } \\
\text { A. Bruszkiewicz } \\
\text { T. Machalski } \\
\text { J. Neugebauer } \\
\text { A. Bruszkiewicz }\end{array}$ \\
\hline $\begin{array}{l}15 \mathrm{IV} \\
1934\end{array}$ & $\begin{array}{l}\text { S. Grzmot-Skot- } \\
\text { nicki }\end{array}$ & $\begin{array}{l}\text { I. ks. Antoni } \\
\text { Aleksandrowicz }\end{array}$ & $\begin{array}{l}\text { A. Bieniarz } \\
\text {-Krzywczyc }\end{array}$ & Ludwik Rau & $\begin{array}{l}\text { G. Górski } \\
\text { T. Machalski } \\
\text { J. Neugebauer } \\
\text { Leyman } \\
\text { Ludwik Rau } \\
\text { ks. S. Karpo- } \\
\text { wicz } \\
\text { ks. L. Żołąd- } \\
\text { kowski }\end{array}$ \\
\hline \multicolumn{6}{|c|}{ Nowy Komitet Wykonawczy } \\
\hline $\begin{array}{l}15 \mathrm{IV} \\
1934\end{array}$ & $\begin{array}{l}\text { Ks. Jan } \\
\text { Borysiuk }^{b}\end{array}$ & $\begin{array}{l}\text { I. ks. Antoni } \\
\text { Aleksandrowicz } \\
\text { II. S. Grzmot } \\
\text {-Skotnicki }\end{array}$ & & Ludwik Rau & $\begin{array}{l}\text { Maksymilian } \\
\text { Jarmulski-bur- } \\
\text { mistrz } \\
\text { M. Prawdzic } \\
\text {-Leyman } \\
\text { Stafiej }\end{array}$ \\
\hline
\end{tabular}

b Borysiuk Jan Kazimierz (1888-1953). Ukończył seminarium duchowne w Żytomierzu i tam w 1911 r. przyjął święcenia. Pracował w Kamieńcu Podolskim jako katecheta, organizował harcerstwo, opiekował się sierocińcem, a od poł. $1920 \mathrm{r}$. został proboszczem parafii Letniowce. W 1. 1922-1925 był kapelanem szpitala wojskowego w Brześciu n. Bugiem oraz ZHP i PCK. W latach 1927-1933 był katechetą gimnazjum w Brześciu. W 1933 roku został proboszczem i dziekanem w Baranowiczach. W czasie II wojny światowej pracował w parafii Nowa Mysz (1943-1944). W 1. 1945-1947 był wikariuszem generalnym diec. pińskiej. Aresztowany w 1948 r., skazany na 10 lat łagrów i skierowany do Sibłagu k. Nowosybirska, a w maju 1950 r. do Omłagu k. Omska, gdzie zmarł w 1953 r. R. Dzwonkowski, Leksykon duchowieństwa polskiego represjonowanego w ZSRR 1939-1988, Lublin 2003, s. 137-138; Kresowi księża harcerze od Kamieńca Podolskiego do Nowogródka. Wspomnienia, opr. H. Dąbkowski, Warszawa 1999, s. 34-36. 


\begin{tabular}{|c|c|c|c|c|c|}
\hline 1 & 2 & 3 & 4 & 5 & 6 \\
\hline $\begin{array}{l}28 \mathrm{I} \\
1935\end{array}$ & ks. Jan Borysiuk & $\begin{array}{l}\text { I. ks. Antoni } \\
\text { Aleksandrowicz } \\
\text { II. S. Grzmot } \\
\text {-Skotnicki }\end{array}$ & $\begin{array}{l}\text { Teodor } \\
\text { Szpakowski }\end{array}$ & R. Kasprzyk & $\begin{array}{l}\text { Adam Haleczko } \\
\text { Rudolf } \\
\text { Kasprzyk, } \\
\text { J. Kubiatowski } \\
\text { Aleksander } \\
\text { Rzepecki, } \\
\text { Kazimierz } \\
\text { Weber, } \\
\text { Ludwik Wolnik }\end{array}$ \\
\hline $\begin{array}{l}26 \mathrm{XI} \\
1936\end{array}$ & $\begin{array}{l}\text { ks. Antoni } \\
\text { Kohutnickic }^{\text {col }}\end{array}$ & $\begin{array}{l}\text { S. Grzmot-Skot- } \\
\text { nicki }\end{array}$ & Czesław Dytz & & $\begin{array}{l}\text { S. Grzmot-Skot- } \\
\text { nicki } \\
\text { R. Kohutnicki } \\
\text { Traugutt-Frej- } \\
\text { man } \\
\text { Ludwik Wolnik }\end{array}$ \\
\hline $\begin{array}{l}30 \\
\text { VIII } \\
1938 \\
\end{array}$ & $\begin{array}{l}\text { ks. Czesław } \\
\text { Fedorowicz }\end{array}$ & $\begin{array}{l}\text { Zygmunt } \\
\text { Kotłubaj }\end{array}$ & & & \\
\hline $\begin{array}{l}16 \\
\text { XII } \\
1938\end{array}$ & $\begin{array}{l}\text { ks. Czesław } \\
\text { Fedorowicz }\end{array}$ & $\begin{array}{l}\text { Zygmunt } \\
\text { Kotłubaj }\end{array}$ & M. Szredych & & $\begin{array}{l}\text { Wilhelm Lawicz } \\
\text { Karol } \\
\text { Wańkowicz, } \\
\text { Ludwik Wolnik, } \\
\text { Konst. } \\
\text { Rdułtowski }\end{array}$ \\
\hline
\end{tabular}

Źródła: ADD, Zespół Archiwum Parafii Baranowicze, Sygn. III/W, Protokoły zebrań Komitetu z: 5, 27 XII 1928; 11 XI, 31 XII 1929; 20, 28 III 1930; 30 I, 2 III, 14 XII 1931; 18 I, 20 V 1932; 15 IV 1934; 28 I 1935; Protokół zdawczo-odbiorczy czynności skarbnika Komitetu Budowy z 25 XI 1936 roku, Zaproszenia na zebranie Komitetu Wykonawczego z 10 XI 1936; 3, 20 IV 1937 roku.

W grudniu 1928 roku został ogłoszony konkurs na wykonanie projektu architektonicznego kościoła. Za najlepsze projekty Komitet Wykonawczy wyznaczył trzy nagrody: I. nagroda 6.000 złotych, II. nagroda 4.000 złotych i III. nagroda 3.000 złotych. Komitet Wykonawczy zastrzegł sobie także prawo zakupu prac nienagrodzonych po cenie 1.000 złotych. Zarówno projekty zakupione jak i nagrodzone miały stać się własnością Komitetu. Do konkursu wymagane były następujące rysunki, wykonane dowolną techniką: plan sytuacyjny w skali 1:500;

${ }^{c}$ Dnia 2 V 1938 roku ksiądz proboszcz Antoni Kohutnicki złożył urząd proboszcza parafii pw. Królowej Korony Polskiej w Baranowiczach. Na jego miejsce przyszedł ks. Czesław Fedorowicz, który dnia 11 V 1939 roku zrzekł się probostwa baranowickiego i opuścił diecezję pińską. Po otrzymaniu odmowy od biskupa podlaskiego o przyjęcie go do tej diecezji, po wybuchu II wojny światowej wyjechał do Francji, gdzie podjął duszpasterstwo wśród Polaków. Zmarł w maju 1940 roku na skutek ran odniesionych w czasie działań wojennych. W. W. Żurek, Początki parafii Matki Bożej Królowej Korony Polskiej w Baranowiczach Poleskich na podstawie księgi inwentarzowej parafii Bbaranowicze z 2 maja 1938 roku, „Archiwa Biblioteki i Muzea Kościelne”, 97 (2012), s. 407-410. 
rzuty kondygnacji w skali 1:200; przekrój podłużny i poprzeczny w miarę potrzeby w skali 1:200; fasady: główna, boczna i tylna w skali 1:200; widok perspektywiczny; obliczenie objętości budowli w metrach sześciennych; kosztorys przybliżony na podstawie kubatury pomnożonej przez cenę 1 metra sześciennego. Prace konkursowe miały być nadesłane do Departamentu Budowlanego Ministerstwa Robót Publicznych w terminie do 20 IV 1929 roku. Komitet Wykonawczy Budowy Kościoła zastrzegł sobie prawo wolnego wyboru zarówno szkicu, jak i osoby której wykonanie tegoż będzie powierzone. Nadesłane projekty miał ocenić sąd konkursowy ${ }^{25}$.

Na ogłoszony konkurs wpłynęło 34 projekty, które były oceniane przez sąd konkursowy w dniu 4 V 1929 roku, złożony z pięciu członków Warszawskiego Koła Architektów oraz czterech członków Komitetu Wykonawczego. Za najlepszy uznano projekt inż. architekta Jana Kukulskiego, a następnie projekty inż. architekta Jana Łukasika i inż. architekta Zdzisława Mączeńskiego. Wybrane w ramach konkursu projekty pozostawały w Ministerstwie Robót Publicznych, za które należało uiścić kwotę w wysokości 14.700 złotych. Na ten cel marszałek Piłsudski wyasygnował w jesieni 1929 roku sumę 5.000 złotych, obiecując stopniowo dalszą pomoc. $Z$ tej sumy wypłacono architektom: Janowi Kukulskiemu 2.000 złotych, Janowi Łukasikowi - 2.000 złotych i Zdzisławowi Mączeńskiemu -1.000 złotych.

Konkurs na projekt przyszłego kościoła rozpatrzony w Warszawie nie zdecydował ostatecznie, który plan zostanie realizowany, a jedynie nagrodził wykonawców najlepszych nadesłanych projektów. Na posiedzeniu dnia 20 III 1930 roku Komitet Obywatelski wybrał projekt nr 15 i zwrócił się do jego autora - inż. Zdzisława Mączeńskiego oraz inż. W. Matuszewicza o złożenie ofert na sporządzenie planu i kosztorysu budowy. Jednak projekt ten ostatecznie nie został zrealizowany ${ }^{26}$.

Z chwilą ukonstytuowania się Komitetu Wykonawczego rozwinięto szeroką akcję mającą na celu zbieranie potrzebnych funduszy i materiałów na budową kościoła. Jego przewodniczący gen. O. Pożerski od samego początku wielokrotnie podkreślał, że nie należy się spodziewać, iż kościół można wybudować wyłącznie z zapomóg ministerialnych. Należy brać pod uwagę wszelkie możliwe sposoby pozyskiwania środków. Na początek zdecydowano wydrukować kwitariusze po 20 i 50 groszy oraz po 1, 2 i 5 złotych. Zdecydowano także aby odpowiedzialni za ten sektor proboszczowie baranowiccy w imieniu Komitetu zwrócili się do biskupów o ogłoszenie we wszystkich parafiach Rzeczypospolitej próśb o składanie ofiar na budowę kościoła w Baranowiczach ${ }^{27}$.

${ }^{25}$ W skład sądu konkursowego weszli: Prezes Rady Ministrów inż. Kazimierz Bartel, architekt Rudolf Świerczyński (profesor Politechniki), gen. Olgierd Pożerski (dowódca garnizonu w Baranowiczach), architekt Aleksander Bojemski (profesor Politechniki); architekci: Ludwik Panczakiewicz, Józef Seredyński, Jan Stefanowicz; Jan Emeryk (starosta powiatu baranowickiego); ks. Lucjan Żołądkiewicz i Eugeniusz Dembiński-Pióro (burmistrz Baranowicz). Tematyczny blog: http:// laurahuta.blogspot.com/2012/02/konkurs-na-projekt-kosciola-krolowej.html (dostęp: 11.03.2013 r.).

${ }^{26}$ ADD, Zespół Archiwum Parafii Baranowicze, Sygn. III/W, Protokół zebrania w dniu 20 III 1930 roku; Tematyczny blog Laurhuta: http://aurahuta.blogspot.com/2012/02/konkurs-na-projekt-kosciola-krolowej.html (dostęp: 11.03.2013 r.).

${ }^{27}$ ADD, Zespół Archiwum Parafii Baranowicze, Sygn. III/W, Protokół zebrania z 31 XII 1929 r. 
Na zebraniu Komitetu dnia 11 XI 1929 roku podniesiono temat aby zwrócić się do ks. Lucjana Żołądkowskiego i ks. majora Franciszka Walaska o ich energiczne zaangażowanie się w zbiórkę pieniędzy i materiałów budowlanych, gdyż im jako proboszczom w Baranowiczach została powierzona działalność reklamowo-propagandowa ${ }^{28}$.

Z odpowiednimi prośbami Komitet Obywatelski Budowy Kościoła zwrócił się do ważnych osobistości w państwie i Kościele o pomoc w budowie; m.in. do marszałka Józefa Piłsudskiego, premiera Felicjana Sławoj Składkowskiego, Prezydium Rady Ministrów, Ministerstwa Wyznań Religijnych i Oświecenia Publicznego, Ministerstwa Robót Publicznych, prymasa Polski Augusta Hlonda i do Episkopatu Polski. Przystąpiono również do szeroko zakrojonej akcji zbiórkowej. Czynione zabiegi przynosiły pewne wpływy finansowe, które przeznaczano stopniowo na zakup materiałów budowlanych ${ }^{29}$.

Zorganizowaniu systematycznego pomnażania środków na planowaną inwestycję miały służyć:

a) Bloczki do zbierania składek rozdane w pierwszym rzędzie członkom Komitetu Obywatelskiego;

b) Zorganizowanie specjalnej akcji zbierania składek na zebraniu celem powołania Komitetu Obywatelskiego w dniu 23 III 1930 roku;

c) Zakupienie z funduszu Komitetu Obywatelskiego dwóch puszek z odpowiednim napisem i ustawienie je w kościele parafialnym i garnizonowym - powierzono ks. Żołądkowskiemu;

d) Odezwę połączoną z listą składek rozesłać do wszystkich urzędów i instytucji w całym państwie - powierzono ks. Żołądkowskiemu i sekretarzowi Bruszkiewiczowi;

e) Złożyć wizyty w powiecie wybitniejszym osobom z pośród ziemiaństwa i przemysłowców, dla pozyskania środków w gotówce i naturze - powierzono gen. Pożerskiemu, ks. Żołądkowskiemu i staroście powiatu baranowickiego Przepałkowskiemu ${ }^{30}$.

Kolejną inicjatywą pozyskiwania środków była propozycja zwrócenia się do wszystkich naczelników urzędów oraz do zarządów instytucji społecznych, aby opodatkowali pracowników oraz członków ich rodzin na ten cel. Ponadto zdecydowano zwrócić się do magistratu miasta z wnioskiem na opodatkowanie organizowanych $\mathrm{w}$ mieście widowisk. Miała być również zredagowana odezwa z zamieszczoną fotografią przyszłego kościoła i przybliżonym kosztem budowy

${ }^{28} \mathrm{Na}$ cele propagandowe wyasygnowano 11 XI 1929 roku kwotę 300 złotych. Uznano za słuszne, aby w sprawie zbiórki zwrócić się do wyższych osobistości w mieście: wojewody nowogródzkiego Zygmunta Beczkowicza, hr. Potockiego, księcia Radziwiłła, posła na sejm - Konstantego Rydułtowskiego, Zygmunta Czarneckiego, Witolda Górskiego, prezesa Organizacji Rolniczych - K. Mackiewicza, inżyniera Mariana Prawdzic-Leymana. ADD, Zespół Archiwum Parafii Baranowicze, Sygn. III/W, Protokół zebrania z 11 XI 1929, 15 IV 1934 roku.

${ }^{29}$ ADD, Zespół Archiwum Parafii Baranowicze, Sygn. III/W, Protokół zebrania z 15 IV 1934 roku.

${ }^{30}$ ADD, Zespół Archiwum Parafii Baranowicze, Sygn. III/W, Protokół zebrania z 20 III 1930 roku. 
- ok. 1.500.000 złotych, która powinna być rozesłana do wszystkich urzędów i instytucji w kraju. Zakładano także drukowanie w dzienniku „Życie Nowogródzkie"31 okresowych sprawozdań z działalności Komitetu Obywatelskiego ${ }^{32}$.

Wszelkie środki pieniężne zebrane na budowę kościoła były ulokowane w Polskiej Kasie Oszczędnościowej w Warszawie i w Komunalnej Kasy Oszczędności w Baranowiczach. Stan salda w dniu sprawozdawczym wynosił prawie 5.000 złotych $^{33}$.

Tab. 2. Zapomogi pieniężne i ofiary na budowę kościoła w Baranowiczach 1929-1931.

\begin{tabular}{|l|c|l|}
\hline \multicolumn{1}{|c|}{ Data wplywu } & Kwota & \multicolumn{1}{c|}{ Od kogo } \\
\hline \multicolumn{1}{|c|}{$\mathbf{2}$} & $\mathbf{2}$ & \multicolumn{1}{c|}{$\mathbf{3}$} \\
\hline październik 1929 & $5.000,00$ & Marszałek Józef Piłsudski \\
\hline listopad 1929 & $1.000,00$ & Marszałek Józef Piłsudski \\
\hline grudzień 1929 & $6.000,00$ & $\begin{array}{l}\text { Rada Ministrów i Ministerstwo Oświaty i Wyznań } \\
\text { Religijnych }\end{array}$ \\
\hline marzec 1930 & $5.000,00$ & Ministerstwo WRiOP \\
\hline maj 1931 & $\begin{array}{c}\text { pokrycie zakupu } \\
\text { placu }\end{array}$ & Ministerstwo Robót Publicznych \\
\hline maj 1931 & 250,00 & Ofiara marszałka Józefa Piłsudskiego \\
\hline do maja 1931 & $5.386,00$ & $\begin{array}{l}\text { Składki i ofiary od osób i instytucji } \\
\text { Sprzedane cegiełki na budowę kościoła } \\
\text { 3 V 1931 }\end{array}$ \\
\hline
\end{tabular}

31 „Życie Nowogródzkie”, dziennik poświęcony sprawom Ziemi Nowogródzkiej, adres redakcji i administracji: Nowogródek, ul. 3 Maja nr 1.

${ }^{32}$ ADD, Zespół Archiwum Parafii Baranowicze, Sygn. III/W, Protokół zebrania z 28 III 1930 roku.

${ }^{33}$ Tamże. 


\begin{tabular}{|c|c|c|}
\hline 1 & $\mathbf{2}$ & $\mathbf{3}$ \\
\hline & $3.000,00$ & Subwencja Prezydium Rady Ministrów \\
& $5.000,00$ & Subwencja Urzędu Wojewódzkiego w Nowo- \\
gródku
\end{tabular}

Źródło: ADD, Zespół Archiwum Parafii Baranowicze, Sygn. III/W, Protokoły zebrań Komitetu z: 11 XI, 31 XII 1929, 20 III 1930 roku; Zestawienie Kasowe Komitetu z 10 V 1931 roku; Zestawienie Kasowe Komitetu za czas od 1 IV 1930 do 14 XII 1931 roku; Sprawozdanie kasowe Komitetu Budowy Kościoła Królowej Korony Polskiej w Baranowiczach za czas od 24 XII 1931 do 24 I 1933 roku; Zestawienie kasowe Komitetu Budowy Kościoła Królowej Korony Polskiej w Baranowiczach na dzień 29 I 1935 roku.

Aż do wiosny 1931 roku budowa kościoła rozwijała się planowo i zgodnie $\mathrm{z}$ harmonogramem. Należało jednak uzgodnić z kurią pińską kwestię stosunku władz kościelnych, cywilnych i wojskowych do planowanej inwestycji kościelnej. Ze uwagi na fakt, że wznoszono wspólną świątynię przez parafię baranowicką i garnizon wojskowy, zwrócono się więc do ordynariusza pińskiego, zapewniając że budujący się obiekt będzie kościołem parafialnym diecezji pińskiej. W swojej odpowiedzi biskup Łoziński określił w następujący sposób swoje stanowisko wobec tego projektu: 
1) Kościół winien być budowany na terenie przynależnym do kościoła, a nie na parceli rządowej, prywatnej lub dzierżawionej;

2) Gospodarzem nowo wybudowanego kościoła jest proboszcz parafii baranowickiej pw. Podwyższenia Świętego Krzyża, wchodzący w skład duchowieństwa diecezji pińskiej;

3) Wojsko w nowo wybudowanym kościele otrzymuje prawo do odbywania wszelkich praktyk religijnych;

4) Regulamin wspólnego korzystania z kościoła i sposób załatwiania spraw gospodarczych będą opracowane w porozumieniu obu proboszczów;

5) Wynikające ewentualne trudności i nieporozumienia rozstrzygać będzie zwierzchność diecezjalna w porozumieniu z kurią polową ${ }^{34}$.

Wszyscy członkowie Komitetu byli usatysfakcjonowani z treści odpowiedzi biskupa z dnia 18 I 1930 roku na ich pismo, jako pokrywające się ze stanowiskiem Komitetu i organizacją przyszłego kościoła.

Dopiero w marcu 1931 roku zaistniała w łonie Komitetu Obywatelskiego różnica zdań co do planowanej inwestycji. Zapytany przez przewodniczącego Komitetu Obywatelskiego Z. Przepałkowskiego ks. Żołądkowski, jak przedstawia się akcja zbierania składek na budowę kościoła wśród ludności katolickiej, ten odpowiedział, że dotychczas nic nie zbierał gdyż powołując się na prawo kanoniczne, uważa działalność Komitetu Obywatelskiego z nielegalną ${ }^{35}$. Odpowiadając ks. Żołądkowskiemu starosta Przepałkowski zwrócił uwagę, że skrupuły, które rzekomo nie pozwoliły mu na przeprowadzania akcji pozyskiwania funduszy na budowę wśród ludności cywilnej, nie stały jednak na przeszkodzie, że był on członkiem zarówno Komitetu Wykonawczego jak i Komitetu Obywatelskiego i zajmował w obu funkcję vice-prezesa od 27 XII 1928 do 30 I 1931 roku$^{36}$.

Tab. 3. Wpływy i wydatki Komitetu Obywatelskiego Budowy Kościoła w Baranowiczach.

\begin{tabular}{|l|l|l|l|}
\hline \multicolumn{1}{|c|}{ Data } & \multicolumn{1}{|c|}{ Dochody } & \multicolumn{1}{c|}{ Wydatki } & \multicolumn{1}{c|}{ Saldo } \\
\hline \multicolumn{1}{|c|}{$\mathbf{1}$} & \multicolumn{1}{|c|}{$\mathbf{2}$} & \multicolumn{1}{c|}{$\mathbf{3}$} & \multicolumn{1}{c|}{$\mathbf{4}$} \\
\hline 30 III 1930 & subwencje rządowe, składki 19515,00 & $14.556,00$ & 4958,85 \\
\hline 3 IX 1930 & 19915,00 & 16225,15 & 3258,85 \\
\hline 31 I 1931 & & & 12670,52 \\
\hline 20 IV 1931 & 29092,00 & 18995,48 & 10096,52 \\
\hline 10 V 1931 & 29596,00 & 27364,00 & 2231,73 \\
\hline 14 XII 1931 & 43596,23 & 42611,60 & 984,00 \\
\hline 20 V 1932 & & & \\
\hline 25 I 1933 & z pozostałością 11262,55 & 9539,99 & 1722,56 \\
\hline
\end{tabular}

${ }^{34}$ ADD, Zespół Archiwum Parafii Baranowicze, Sygn. III/W, Pismo Komitetu do biskupa pińskiego z 22 VI 1929 roku, Biskup piński do prezesa Komitetu w Baranowiczach z 18 I 1930 (L. 227/30).

${ }^{35}$ Odpowiadając ks. major Walasek stwierdził, że jego jako osobę duchowną również obowiązuje prawo kanoniczne, co nie przeszkadzało mu dotychczas zebrać na budowę Kościoła kilka tysięcy złotych wśród wojska i ich rodzin.

${ }^{36}$ ADD, Zespół Archiwum Parafii Baranowicze, Sygn. III/W, Protokół zebrania z 2 III 1931 roku. 


\begin{tabular}{|l|l|l|l|}
\hline \multicolumn{1}{|c|}{$\mathbf{1}$} & \multicolumn{1}{c|}{$\mathbf{c}$} & \multicolumn{1}{c|}{$\mathbf{c}$} & \multicolumn{1}{c|}{$\mathbf{4}$} \\
\hline 21 XII 1933 & 13617.85 & 11363,54 & 2254,31 \\
\hline 1 I 1934 & od 1930 do 1 I 1934-56560,56 & 54410,15 & 2150,41 \\
\hline 29 I 1935 & 3542,48 & 1548,89 & 1993,59 \\
\hline do 5 X 1936 & 2335,36 & 1133,45 & 3079,60 \\
\hline
\end{tabular}

Źródło: ADD, Zespół Archiwum Parafii Baranowicze, Sygn. III/W, Protokół zebrania z 28 III 1930, 10 V, 14 XII 1931 roku; Protokół zdawczo-zbiorczy skarbnika Komitetu Obywatelskiego Budowy kościoła z 3 IX 1930 roku, Sprawozdanie Kasowe Komitetu z 20 IV, 10 V 1931, za czas od 24 XII 1931 do 24 I 1934 roku, .Zestawienie przychodów i rozchodów za czas od powstania Komitetu do dnia 1 I 1934 roku, Zestawienie wpływów i wydatków za rok 1934 Komitetu Budowy Kościoła w Baranowiczach; Sprawozdanie kasowe od 1 I 1934 do 29 I 1935 roku.

Dnia 17 II 1931 roku udała się do Warszawy delegacja Komitetu Obywatelskiego Budowy Kościoła w osobach: starosta Z. Przepałkowski, gen. Stanisław Grzmot-Skotnicki, ks. mjr Franciszek Walasek. Uzyskali oni w Ministerstwie Spraw Wojskowych subwencję w kwocie 10000,00 złotych i w Ministerstwie Wyznań Religijnych i Oświecenia Publicznego obietnicę otrzymania subwencji na kwotę 3000,00 złotych oraz obietnicę członków rządu na pomoc finansową w miarę możliwości. Te stosunkowo niewielkie kwoty uzyskane przez delegację, miały tłumaczyć trudną sytuację ekonomiczną kraju. Ponadto minister Pracy i Opieki Społecznej - gen. Mieczysław Norwid-Neugebauer poinformował przewodniczącego Komitetu o przekazaniu placu pod planowaną budowę w Baranowiczach na własność Komitetu ${ }^{37}$.

W Warszawie delegaci pertraktowali z architektami: W. Matuszewskim, Zdzisławem Mączyńskim i Janem Kukulskim w sprawie planów budowy ${ }^{38}$. Z wymienionych trzech architektów warszawskich, inż. Jan Kukulski złożył najkorzystniejszą ofertę na opracowanie planów kościoła i prowadzenie jego budowy. Za wykonanie wymienionych prac łącznie z dozorem technicznym zażądał wynagrodzenie w wysokości 18600,00 złotych.

Po szczegółowym zapoznaniu się z jego ofertą, zarząd Komitetu Obywatelskiego na posiedzeniu dnia 28 II 1931 roku powziął uchwałę o podpisanie stosownej umowy z inż. Kukulskim. Umowa została podpisana dnia 2 III 1931 roku. Kukulski zobowiązał się dostarczyć na początek Komitetowi Obywatelskiemu plan sytuacyjny pod inwestycję wraz z wytyczeniem miejsc przeznaczonych na skład materiałów budowlanych i dołu na wapno.

Jeszcze tego dnia na zebraniu Komitet zdecydował o zakupie pierwszej partii materiałów budowlanych: cegły zwykłej 25.000 sztuk, cegły prasowanej 25.000

${ }^{37}$ W maju 1931 roku Minister Robót Publicznych gen. Norwid-Neugebauer obiecał pomoc Komitetowi w formie przyjęcia kosztu nabycia placu pod budowę kościoła przez Skarb Państwa. ADD, Zespół Archiwum Parafii Baranowicze, Sygn. III/W, Protokół zebrania z 10 V 1931 roku.

${ }^{38}$ Uprzednio na posiedzeniu Komitetu 30 I 1930 roku z nadesłanych dwóch projektów budowy kościoła, większością głosów wybrano projekt nr 1. Niestety nie wiemy kto był jego wykonawcą. 
sztuk $^{39}$, kamienia polnego $500 \mathrm{~m}^{3}$, wapna 8 wagonów, cementu 1 wagon ${ }^{40}$.

Mimo podpisania umowy dnia 2 III 1931 roku między Komitetem a architektem Janem Kukulskim, ten ostatni poinformował zarząd Komitetu Obywatelskiego, że do momentu rozpoczęcia formalnego toku spraw, a więc zatwierdzenia wstępnego projektu budowy w obu kuriach: rzymskokatolickiej i wojskowej oraz projektu z obliczeniami statystycznymi w tychże kuriach i w Urzędzie Wojewódzkim, nie będzie mógł wykonywać dalszych prac. Te dwa etapy muszą poprzedzić sporządzenie kosztorysu i kompletu rysunków wykonawczych. Architekt ufał, że pomimo tak długiego wstrzymania prac, ks. dziekan Lucjaan Żołądkowski będzie w stanie je reaktywować, aby mógł wreszcie sporządzić właściwe plany i zająć się sprawami budowlanymi ${ }^{41}$.

Do maja 1931 roku został opracowany wstępny plan budowy i rozpoczęto już prace, a prezes Komitetu Obywatelskiego porozumiał się osobiście w tej sprawie z ordynariuszem pińskim Zygmuntem Łozińskim. Pomimo uprzedniego zdawałoby się przychylnego stanowiska biskupa pińskiego, wysunął on szereg zastrzeżeń pod adresem sporządzonego projektu, skutkiem czego został on częściowo przerobiony. Na dzień $3 \mathrm{~V} 1931$ roku zaplanowano uroczyste rozpoczęcie budowy poprzez założenie i poświęcenie kamienia węgielnego. Tymczasem biskup piński kategorycznie odmówił przybycia na uroczystość i w ogóle zakwestionował legalność działania dotychczasowego Komitetu Obywatelskiego ${ }^{42}$. Generał Stanisław Grzmot-Skotnicki interweniując w Ministerstwie Robót Publicznych

${ }^{39}$ Cegłę zdecydowano zakupić w fabryce ceramicznej Swojatycze, na warunkach na jakich zawarł umowę z tą fabryką Wydział Powiatowy Sejmiku Baranowickiego na dostawę cegły przy budowie szpitala. Jednak inżynier Kukulski postawił wniosek, aby cegłę ze Swojatycz poddać analizie na ciśnienie, na co zebrani członkowie Komitetu wyrazili zgodę. ADD, Zespół Archiwum Parafii Baranowicze, Sygn. III/W, Odpis z pierwszej karty Książki Zleceń Budowy - z dnia 30 IV 1931 roku.

${ }^{40}$ ADD, Zespół Archiwum Parafii Baranowicze, Sygn. III/W, Protokół zebrania z 28 II i 3 III 1931 roku.

${ }^{41}$ Przy tej okazji inżynier Jan Kukulski wyraził zgodę na zaangażowanie przy budowie pana Adamusa, tylko jako siłę techniczną, opłacaną przez Komitet i będącą poza właściwym kierownictwem robót.

Niestety nie znamy daty tego pisma, zachowała się jedynie strona druga listu z informacją o załączeniu do niego 12 załączników, których również nie znamy. ADD, Zespół Archiwum Parafii Baranowicze, Sygn. III/W, Pismo Jana Kukulskiego do Komitetu Obywatelskiego (Warszawa), brak daty.

${ }^{42}$ Kwestią sporną była sprawa prezesury Komitetu Obywatelskiego, którą to funkcję pełniły dotychczas osoby świeckie, aktualnie gen. Stanisław Grzmot-Skotnicki. Pińska Kuria Biskupia stała na stanowisku, powołując się na prawo kanoniczne, że funkcję prezesa Komitetu Obywatelskiego Budowy Kościoła winna z urzędu pełnić osoba duchowna, w tym przypadku ks. kanonik Lucjan Żołądkowski, na którego prezesurę jednak Komitet Obywatelski z powodów zasadniczych nie mógł się zgodzić. Skutki tego nieporozumienia odbiły się bardzo ujemnie na działalności Komitetu Obywatelskiego. Wszelkie jego poczynania od tego czasu pozostawały w zawieszeniu. Dopiero po odejściu ks. Żołądkowskiego ze składu Komitetu (drugi zastępca), przedmiot nieporozumienia pomiędzy Komitetem Obywatelskim a Pińską Kuria Biskupią został usunięty i zaistniały warunki do normalnej pracy Komitetu. 
(Pracy i Opieki Społecznej) w sprawie Komitetu Obywatelskiego i pomocy finansowej na budowę usłyszał od ministra - gen. Mieczysława Norwida-Neubebauera stwierdzenie, że realizacja przez Komitet Obywatelski budowy świątyni parafialnej cywilno-wojskowej jest niemożliwa, wobec tego zaproponował minister rozpocząć budowę kościoła w Baranowiczach jako garnizonowego. Po zreferowaniu tej sugestii ministra przez gen. Stanisława Grzmot-Skotnickiego na zebraniu Komitetu Obywatelskiego dnia 10 V 1931 roku, zebrani 5 głosami (przy 4 przeciwnych) przegłosowali uchwałę, aby przystąpić do budowy kościoła wyłącznie garnizonowego, nie przesądzając co do ostatecznej formy administrowania nim po ukończeniu jego budowy ${ }^{43}$.

Mimo kilkakrotnych próśb kierowanych przez Komitet Wykonawczy, do listopada 1929 roku Ministerstwo Robót Publicznych nie przekazało placu pod budowę kościoła, wyjaśniając iż bez akceptacji Sejmu nie ma możliwości nawet jego sprzedaży. W tej sytuacji zarząd Komitetu postanowił skierować kolejną petycję z prośbą o przyśpieszenie przekazania placu, by móc go ogrodzić i gromadzić na nim materiały budowlane ${ }^{44}$.

Kiedy plac pod budowę kościoła, chociaż nie formalnie, został nabyty i ogrodzony, rozpoczęto zwozić materiały budowlane. Należało jeszcze uzyskać jego notarialny akt własności, by przekazać go parafii garnizonowej w Baranowiczach. Oczekiwano także na zatwierdzenie przez wojskową kurię biskupią wstępnego projektu budowy. W tej sprawie interweniował w kurii polowej i w starostwie baranowickim inż. Jan Kukulski, lecz bez rezultatu. Ks. prałat Michalski przedstawił inż. Kukulskiemu stanowisko biskupa polowego Stanisława Galla. Kuria wojskowa nie mogła przyjąć planów kościoła do zatwierdzenia, ze względu na brak załatwienia formalnego sprawy zakupu placu pod budowę oraz charakteru przyszłego kościoła. Podobne zastrzeżenia zgłaszała Pińska Kuria Biskupia. Z tego powodu sprawa zatwierdzenia wstępnego projektu budowy oraz sporządzenia planu, do początku lipca 1931 roku nie została zakończona. Zdaniem inż. Kukulskiego nie można było sporządzić planu budowy kościoła bez załatwienia formalności w Nowogródzkim Urzędzie Wojewódzkim. Powyższe zastrzeżenia przedstawił inż. Kukulski zarządowi Komitetu Obywatelskiego. W związku z powyższym zdecydowano o wysłaniu delegacji Komitetu Obywatelskiego do biskupa polowego w celu przedstawienia mu projektu budowy i uzyskania jego aprobaty. Delegacja miała także rozmawiać z ministrem Neugebauerem o wydanie aktu własności placu, na którym gromadzono materiał. ${ }^{45}$.

Dla pozyskiwania wpływów finansowych, na początku 1932 roku przedstawiono Komitetowi Obywatelskiemu projekt wydania odezwy z fotografią projektu kościoła i znaczkami po 10, 20 i 50 groszy, na ogólną sumę 20 złotych do

${ }^{43}$ ADD, Zespół Archiwum Parafii Baranowicze, Sygn. III/W, Protokół zebrania z 10 V 1931 roku.

${ }^{44}$ ADD, Zespół Archiwum Parafii Baranowicze, Sygn. III/W, Protokół zebrania z 11 XI 1929 roku.

${ }^{45}$ ADD, Zespół Archiwum Parafii Baranowicze, Sygn. III/W, J. Kukulski do Komitetu Budowy Kościoł z 7 i 17 VII 1931 roku (Warszawa), J. Kukulski do starosty w Baranowiczach z 17 VII 1931 roku (Warszawa), Komitet Budowy do Kurii Wojskowej w Warszawie z 11 VII 1931 roku 
każdej odezwy. Te zdecydowano wysłać do instytucji, urzędów i osób prywatnych w całej Polsce. Komitet Obywatelski zaaprobował przedstawiony projekt i uchwalił powierzenie wysyłki odezw poszczególnym osobom:

Generał Stanisław Grzmot-Skotnicki - do dywizji, brygad, pułków i urzędów wojskowych;

A. Bruszkiewicz - do urzędów państwowych i samorządowych, do związków wojskowych;

Helena Terajewicz - do członków stowarzyszeń kobiecych;

ks. dziekan Lucjan Żołądkiewicz - do parafii i duchowieństwa;

G. Górski - do związków i stowarzyszeń ziemiańskich;

ks. Antoni Aleksandrowicz - do instytucji i osób ${ }^{46}$.

Kolejną możliwością pozyskiwania funduszy było przyjęcie w marcu 1932 roku przez Komitet Obywatelski protektoratu nad filmem Król królów, który wyświetlany był w jednym z kin w Baranowiczach. Z tego tytułu Komitet otrzymał kwotę 250 złotych i podatek miejski za cały czas wyświetlania filmu ${ }^{47}$.

Rozesłane do szeregu osób i stowarzyszeń listy ofiar, skutkowały wpływami pieniężnymi. Zwrócono się do Rady Naczelnej Związku Ziemian w Warszawie, centrali organizacji kobiecych, referatu bezpieczeństwa miejscowego starostwa oraz wszelkich możliwych związków i organizacji o nadesłanie adresów oddziałów w celu rozesłania list ofiar instytucjom miejscowym, lekarzom, adwokatom, rejentom itp.

W maju 1931 roku do wykonania prac przygotowawczych pod budowę zaangażowano bezrobotnych, którzy byli wynagradzani z funduszu starosty powiatu baranowickiego. Na początku marca 1932 roku zarząd Komitetu Obywatelskiego zwrócił się do starosty baranowickiego - Neugebauera o przydzielenie do pracy bezrobotnych. Ponieważ starosta baranowicki nie otrzymał do tej pory funduszy z Urzędu Wojewódzkiego na zatrudnienie bezrobotnych, dlatego też nie udzielił wiążącej odpowiedzi ${ }^{48}$.

Wciąż pozostawała nie załatwiona ostatecznie sprawa charakteru przyszłego kościoła: parafii wojskowej czy diecezjalnej. Kwestię tę zgłaszał członek Komitetu Wykonawczego i późniejszego Komitetu Obywatelskiego, proboszcz i dziekan baranowicki ks. Luucjan Żołądkowski. Prezes Komitetu (od 14 XII1931) gen. Stanisław Grzmot-Skotnicki był zdania, że aktualnie najważniejszą rzeczą jest wybudowanie kościoła, a kwestia jego ostatecznej przynależności może być rozstrzygnięta po ukończeniu budowy. Ten tok myślenia w praktyce był niemożliwy do realizowania. Sprzeciwiało się to prawu kościelnemu, co sygnalizowała „strona kościelna” i blokowało procedury prawne z przyjęciem i zatwierdzeniem ostatecznym planu budowy świątyni ${ }^{49}$.

${ }^{46}$ ADD, Zespół Archiwum Parafii Baranowicze, Sygn. III/W, Protokół zebrania z 18 I 1932 roku.

${ }^{47}$ ADD, Zespół Archiwum Parafii Baranowicze, Sygn. III/W, Protokół zebrania z 2 III 1932 roku.

${ }^{48}$ Tamże.

${ }^{49}$ ADD, Zespół Archiwum Parafii Baranowicze, Sygn. III/W, Protokół zebrania z 18 I 1932 roku. 
Mimo braku rysunków wykonawczych budowy i w ogóle ich zatwierdzenia, na zebraniu Komitetu Obywatelskiego w marcu 1932 roku zdecydowano, że na wiosnę tego roku kontynuowane będą prace przy fundamentach i zwózka kamienia ze starych fundamentów mieszkalnych budynków wojskowych z czasów I wojny światowej (po Niemcach). Komitetu uważał, że biskup polowy Galla wyda zgodę co do formy zewnętrznej kościoła i zatwierdzi jego plany, gdy Polowa Kuria Biskupa przejmie prawo własności placu kościelnego. To otworzyło by możliwość starań o zatwierdzenie strony technicznej projektu w Dyrekcji Robót Publicznych. Wyjście z budową murów ścian na powierzchnię ziemi na części fundamentów już wykończonych z pewnością wpłynęłoby na zwiększenie ofiarności wiernych ${ }^{50}$. Tymczasem, aby nie opóźniać realizacji procedury własności placu kościelnego, Komitet Obywatelski zdecydował zawarcie aktu kupna-sprzedaży placu kościelnego z delegatem Dyrekcji Robót Publicznych w Baranowiczach ${ }^{51}$. Dokonanie aktu kupna-sprzedaży placu kościelnego z delegatem Dyrekcji Robót Publicznych, nie doszło do skutku. Urząd Wojewódzki Dyrekcji Robót Publicznych zażądał od Komitetu podania osoby prawnej ze strony Kościoła katolickiego lub innej, która przyjęłaby odpowiedzialność za spłatę do Skarbu Państwa należności za plac, ponieważ Komitet Obywatelski Budowy może się rozwiązać, po wykonaniu swych zadań. Taka osoba nie została wskazana przez zarząd Komitetu Obywatelskiego, przez co Komitet nie mógł sfinalizować aktu kupna-sprzedaży, a tym samym nie mógł stać się właścicielem placu ${ }^{52}$.

W związku z trudnością wskazania przez Komitet Obywatelski osoby odpowiedzialnej za zobowiązania finansowe wobec państwa po rozwiązaniu Komitetu Obywatelskiego, biskup Kazimierz Bukraba zaproponował nabycie placu pod budowę kościoła za gotówkę. Na ten zakup potrzeba było ok. 3200,00 złotych. Natomiast w styczniu 1935 roku Komitet dysponował kwotą 1993,00 złotych. Na zebraniu Komitetu dnia 28 I 1935 roku postawiono wniosek, by z braku odpowiedniej gotówki wypłacić jednorazowo 500 złotych, a resztę spłacać ratami. Wniosek ten przyjęto jednogłośnie. Na skutek wniesionej prośby do Ministerstwa Robót Publicznych, uzyskano zgodę tegoż ministerstwa na rozłożenie ceny kupna placu na 10 rat rocznych. Na zebraniu Komitetu dnia 12 III 1935 roku starosta powiatu baranowickiego Jerzy Neugebauer stwierdził, że dotychczasowa sprawa kupna placu nie została załatwiona, ponieważ Nowogródzki Urząd Wojewódzki nie wie-

${ }^{50}$ Co do budowy częściowej ścian kościoła inżynier Leyman wyjaśnił, że prace budowlane mogą być prowadzone tylko przy zachowaniu należytej kolejności - mianowicie najpierw należy zalać całe fundamenty, a dopiero potem przystąpić do budowy ścian. Wykonanie ścian (muru) musi nastąpić równocześnie na całej powierzchni fundamentów, gdyż mury wykonane na raty będą się później rysować, czyli pękać. ADD, Zespół Archiwum Parafii Baranowicze, Sygn. III/W, Protokół zebrania z 21 XII 1933 roku.

${ }^{51}$ Komitet mieli reprezentować: ks. Ludwik Żołądkowski, inż. Marian Prawdzic-Layman, mjr Ludwik Rau. Zakupiony plac kościelny Komitet planował przekazać Kurii Biskupiej Polowej lub Pińskiej. ADD, Zespół Archiwum Parafii Baranowicze, Sygn. III/W, Protokół zebrania z 20 V 1932 roku.

${ }^{52}$ ADD, Zespół Archiwum Parafii Baranowicze, Sygn. III/W, Protokół zebrania z 25 I 1933 roku. 
dział, że Komitet jest osobą prawną. Starosta proponował wybrać dwóch członków Komitetu upoważnionych do podpisania aktu kupna. Załatwienie tej sprawy powierzono ks. Janowi Borysiukowi i inżynierowi Janowi Adamusowi ${ }^{53}$.

Ustalenie przyszłego gospodarza kościoła i jego ostatecznego charakteru było przedmiotem nieporozumień między Komitetem Obywatelskim a kuria pińską i polową. Zdaniem prezesa Komitetu Obywatelskiego gen. Stanisława Grzmot -Skotnickiego winę w wytworzeniu takiego stanu rzeczy ponosił w pewnym stopniu ks. kanonik Lucjan Żołądkowski. Swoje zdanie opierał na pewnych faktach i dokumentach znajdujących się w aktach Komitetu Obywatelskiego, jednak nie podał żadnych szczegółów uczestnikom zebrania. $Z$ tego powodu budowa kościoła w 1932 roku stała w martwym punkcie, gdyż działalność Komitetu Obywatelskiego nie miała oparcia ani w kurii pińskiej, ani też polowej. Taki stan rzeczy nie mógł się przedłużać. Należało dążyć do usunięcia dotychczasowych trudności i przystąpić do pracy. W tej sytuacji przewodniczący Komitetu Obywatelskiego zaproponował cofnięcie powziętej na posiedzeniu w dniu 10 IV 1931 roku uchwały o budowie kościoła wyłącznie garnizonowego, co mogło doprowadzić do poprawnych relacji między Komitetem Obywatelskim a kuriami biskupimi. Dodatkowo po śmierci biskupa Zygmunta Łozińskiego (†26 III 1932), na początku sierpnia tego roku rządy w diecezji objął bp Kazimierz Bukraba ${ }^{54}$, który odnosił się przychylnie do poczynań Komitetu. Wokół tego tematu wywiązała się żywa dyskusja uczestników zebrania, a głos zabierali poszczególni członkowie Komitetu. Na koniec zgodzono się, że osobą prawną w sprawach kościelnych (np. zakup placu) jest kuria biskupia, że na czele Komitetu Obywatelskiego może stać osoba cywilna, bo prawo kanoniczne tego nie zabrania, natomiast referentem biskupa w tych sprawach jest miejscowy proboszcz. Wreszcie padła propozycja by prosić biskupa K. Bukrabę o objęcie funkcji honorowego prezesa Komitetu, co może doprowadzić do usunięcia nieporozumień. Do biskupa pińskiego miał się udać na początku lutego 1933 roku prezes Komitetu Obywatelskiego gen. Grzmot -Skotnicki.

Nie znamy daty wizyty prezesa u bpa K. Bukraby. Na pewno odbyła się ona po 25 II 1933 roku, gdyż dopiero na trzecim w 1933 roku zebraniu Komitetu

${ }^{53}$ ADD, Zespół Archiwum Parafii Baranowicze, Sygn. III/W, Protokół zebrania z 28 I, 12 III, 15 IV 1935 roku.

${ }^{54}$ Bp Bukraba Kazimierz (1885-1946) - biskup diecezjalny w Pińsku. Urodził się w Grodnie w rodzinie urzędniczej. Teologię studiował w Petersburgu, następnie w Insbrucku. Święcenia kapłańskie przyjął dnia 2 II 1909 roku w Krakowie. Pracował w Mińsku Litewskim jako wikariusz i prefekt szkół, od 1912 roku był proboszczem w Pińsku i rektorem kościoła św. Karola Boromeusza, od 1917 roku proboszczem w Nowogródku, od 1928 roku w Brześciu. W czasie pierwszej wojny światowej był kilkakrotnie więziony jako zakładnik. Mianowany biskupem pińskim dnia 10 VII 1932 roku. Konsekrację biskupią przyjął dnia 21 VIII 1932 roku w Wilnie. Rządy diecezją objął dnia 28 VIII 1932 roku. Był drugim ordynariuszem diecezji pińskiej, po zmarłym biskupie Zygmuncie z Łozin-Łozińskim (1925-1932). W 1934 roku ogłosił statuty synodu diecezjalnego, kilkakrotnie wizytował diecezję, rozbudował sieć parafialną i utworzył 2 nowe dekanaty, sprowadził do pracy w diecezji zakony. Po wybuchu II wojny światowej musiał opuścić stolicę diecezji. Rezydował we Lwowie 1939, Warszawie 1942 i od 1944 roku w Łodzi, gdzie zmarł. A. Petrani, Bukraba Kazimierz, w: EK, t. 2, Lublin 1985, kol. 1189-1190. 
Obywatelskiego - dnia 9 maja tego roku prezes przedstawił zebranym sentencję spotkania - dzięki tej wizycie zostaną usunięte niebawem nieporozumienia istniejące pomiędzy Komitetem Obywatelskim a Pińską Kurią Biskupią ${ }^{55}$.

W grudniu 1933 roku sprawa budowy kościoła w Baranowiczach weszła na nowe tory. Na zabraniu dnia 21 XII 1933 roku przewodniczący Komitetu Obywatelskiego gen. Grzmot-Skotnicki, po odczytaniu protokołu z ostatniego zebrania (9 maja tego roku) zreferował funkcję prezesa Komitetu Obywatelskiego, a mianowicie że według prawa kanonicznego winna to być osoba duchowna. Po odejściu z Komitetu ks. Lucjana Żołądkowskiego (drugi zastępca), nie było przeszkód, aby prezesem została osoba duchowna. Dotychczasowy prezes gotów był złożyć przewodnictwo Komitetem i zaproponował zebranym osobę obecnego proboszcza baranowickiego i dziekana ks. Jana Borysiuka, do którego w tej sprawie należało się zwrócić. Wraz z ustąpieniem obecnego prezesa należało zamknąć działalność dotychczasowego Komitetu Obywatelskiego Budowy Kościoła w Baranowiczach oraz zwołać ogólne zebranie wszystkich parafian i dokonać wyboru nowego komitetu o poszerzonym składzie ${ }^{56}$.

W dotychczasowym działaniu Komitet nie kierował się względami osobistymi ani też partyjnymi, względnie niezdrowymi ambicjami lecz przyświecał mu cel do jakiego został powołany, a jego zarząd zawsze był gotów poddać się decyzjom władz kościelnych. Ponieważ na wiosnę 1934 roku różnice zdań zarządu Komitetu Obywatelskiego a Pińską Kurią Biskupią zostały usunięte (dymisja prezesa Komitetu, jako osoby świeckiej), nic nie stało na przeszkodzie w prowadzeniu prac przy budowie kościoła. W tej sytuacji, niejako przełomowej w historii działalności Komitetu oraz budowy kościoła, zarząd Komitetu Obywatelskiego zdecydował na zebraniu dnia 15 IV 1934 roku ustąpić57.

Po rezygnacji prezesa gen. Grzmot-Skotnickiego, na zwołanym nadzwyczajnym walnym zebraniu wszystkich członków Komitetu w lokalu kina „Apollo”, dokonano wyboru nowych władz Komitetu, w myśl wskazań biskupa pińskiego Kazimierza Bukraby, że może nim kierować tylko proboszcz parafii baranowickiej - ks. dziekan Jan Borysiuk. Na zebranie przybyło 148 członków. Na początku wybrano jednomyślnie przez aklamację przewodniczącego zebrania ks. Borysiuka. Udzielił on głosu dotychczasowemu prezesowi Komitetu generałowi Grzmot -Skotnickiemu, który odczytał proponowaną przez ustępujący Komitet listę nowego Komitetu (Wykonawczego) i komisji rewizyjnej. Na członków przyszłego Komitetu zostali zaproponowani: ks. Antoni Aleksandrowicz - kapelan W. P.,

${ }^{55}$ Niestety jeszcze w grudniu 1933 roku architekt Jan Kukulski w piśmie do Komitetu Obywatelskiego skarżył się, że realizacja budowy przewleka się już trzy lata. Zaniepokojony tym stanem pytał, czy jest nadzieja aby sezon budowlany w 1934 roku mógłby być wykorzystany na prowadzenie prac. Niestety nikt z Komitetu na ten list polecony nie odpowiedział nadawcy przez prawie 3 miesiące. ADD, Zespół Archiwum Parafii Baranowicze, Sygn. III/W, Protokół zebrania z 25 I, 9 V 1933 roku, Jan Kukulski do Komitetu Obywatelskiego z 21 XII 1933, 8 III 1934 rok (Warszawa).

${ }^{56}$ ADD, Zespół Archiwum Parafii Baranowicze, Sygn. III/W, Protokół zebrania z 21 XII 1933 roku.

${ }^{57}$ ADD, Zespół Archiwum Parafii Baranowicze, Sygn. III/W, Protokół zebrania z 15 IV 1934 roku. 
inż. Jan Adamus, ppłk. Zygmunt Fischer - dowódca 9 Dywizjonu Artylerii Konnej, burmistrz Maksymilian Jarmulski, Zygmunt Kotłubaj - obywatel ziemski, ppłk Jan Malkiewicz, Jerzy Neugebauer - starosta powiatu baranowickiego, mjr Ludwik Rau - sekretarz, kwatermistrz 78 Pułku Piechoty, Aleksander Rzepecki - dyrektor Ubezpieczalni Społecznej, dyrektor Stafiej, gen. Stanisław Grzmot -Skotnicki, kpt. Władysław Trzecieski, ppłk. dyplomowany Andrzej Juliusz Uthke - dowódca 20 Pułku Artylerii Lekkiej, Kazimierz Weber - dyrektor Szkoły Handlowej Polskiej Macierzy Szkolnej. Do komisji rewizyjnej zaproponowano: rejenta Bychowica, dyrektora Gracjana Czyżewskiego, naczelnika Kowalewskiego, pułk. Mieczysława Sokół-Szachina, pułkownika dr Trojanowskiego ${ }^{58}$.

Na zakończenie walnego zebrania jego przewodniczący ks. Borysiuk dziękując za wybór zapewnił, że nie będzie szczędził pracy i trudu, by dzieło budowy kościoła należycie prowadzić. W tej pracy liczył na ofiarność i poparcie parafian oraz wyraził nadzieję, że tak jak dotychczas, wojsko będzie wspierało budowę kościoła $^{59}$.

Na kolejnym zebraniu dnia 13 VII 1934 roku w lokalu magistratu miasta wybrano skład nowego Komitetu Wykonawczego:

1. Prezes - ks. Jan Borysiuk, dziekan baranowicki,

2. I. Zastępca prezesa - gen. Stanisław Grzmot-Skotnicki,

3. II. Zastępca prezesa - ks. Antoni Aleksandrowicz,

4. Sekretarz - mjr Ludwik Rau,

5. Zastępca sekretarza - dyrektor Kazimierz Weber,

6. Skarbnik - Teodor Szpakowski, naczelnik Kasy Skarbowej,

7. Kierownik robót publicznych - inż. Jan Adamus.

$\mathrm{Na}$ lipcowym zebraniu podjęto uchwałę $\mathrm{w}$ sprawie sfinalizowania zakupu placu kościelnego, w której zdecydowano, że prezes Komitetu ks. Jan Borysiuk i sekretarz mjr Ludwik Rau zwrócą się do Urzędu Wojewódzkiego o wystawienie aktu notarialnego kupna placu. Na zakończenie zebrania podkreślono, że należy zintensyfikować propagandę prasową o budowie kościoła w Baranowiczach, której podjął się ks. Antoni Aleksandrowicz. Generał Grzmot-Skotnicki przypomniał, że należy akcję zbiórki rozszerzyć na parafian cywilnych ${ }^{60}$.

Nowy prezes Komitetu po swoim wyborze w lipcu 1934 roku przedstawił się listownie w lipcu 1934 roku architektowi Janowi Kukulskiemu w Warszawie i zaznaczył, iż na razie nie jest jeszcze wtajemniczony w całkowity bieg spraw. W odpowiedzi na list ks. Borysiuka, Kukulski zrelacjonował dotychczasowy tok spraw związanych z jego powinnościami w zagadnieniu budowy Kościoła. Wspomniał, że dnia 2 III 1931 roku Komitet Budowy Kościoła zawarł z nim formalną umowę zarejestrowaną w Urzędzie Skarbowym w Baranowiczach, na całokształt prac architektonicznych projektu i kierownictwa budowy kościoła. W marcu

${ }^{58}$ ADD, Zespół Archiwum Parafii Baranowicze, Sygn. III/W, Protokół walnego zebrania z 15 IV 1934 roku.

${ }^{59}$ ADD, Zespół Archiwum Parafii Baranowicze, Sygn. III/W, Protokół walnego zebrania z 15 IV 1934 roku.

${ }^{60}$ Tamże; Lista obecnych za zebraniu członków Komitetu Wykonawczego w dniu 12 III 1935 roku. 
tego roku inżynier Kukulski sporządził projekt wstępny kościoła, który został przez Komitet zaakceptowany, a przedstawiony w Pińskiej Kurii Biskupiej został w zasadzie przyjęty. Jednak w Wojskowej Kurii Polowej w Warszawie nie został dopuszczony do przedstawienia i zatwierdzenia na skutek sporu między kuriami (wojskową i pińską) o sprawy formalne i prawne przyszłego kościoła. Nie bacząc na to, Komitet zdecydował o zalaniu fundamentów kościoła według rysunków Kukulskiego, oprócz części absydalnej. Mimo najszczerszych chęci architekta co do wykonania projektu kościoła i zatwierdzenia go przez władze, sprawa nie mogła być sfinalizowana z powodu wyżej opisanego stanowiska obu kurii. Na wielokrotne nalegania i pytania architekta Kukulskiego do Komitetu o dalsze losy budowy, ten poinformował dnia 30 I 1933 roku o szybkim podjęciu planowanych prac. Jednak po tej deklaracji nastąpiło półtoraroczne milczenie ze strony Komitetu i dopiero w lipcu 1934 roku nowy prezes Komitetu - ks. Borysiuk nawiązał kontakt z architektem Kukulskim.

Przy tej okazji Kukulski odniósł się do sprawy powierzenia przez nowy zarząd Komitetu kierownictwa robót budowlanych miejscowemu inżynierowi Janowi Adamusowi. Kukulski przypomniał prezesowi, że według punktu 4 par. 1 wspomnianej umowy z 2 III 1931 roku, tylko on posiada prawo nadzoru budowlanego. Już przy pierwszych pracach budowlanych przy fundamentach, w porozumieniu z Komitetem, zastępcą Kukulskiego przy pracach w Baranowiczach został wyznaczony Stanisław Gedymin z Baranowicz, płatny z honorarium inżyniera Kukulskiego, na zasadzie umowy prywatnej między nimi. Ta umowa nie została dotychczas rozwiązana i obowiązuje. Wyklucza to więc możność powierzenia i angażowania do dozoru budowlanego kogokolwiek, co należy do inżyniera Kukulskiego ${ }^{61}$.

Wnowej sytuacjiinżynier Kukulskizdecydowałsię, aby przybyćdo Baranowicz. W towarzystwieks. Borysiuka i inż.Adamusa dokonał lustracji dotychczas wykonanych prac i zgromadzonego materiału. Wszyscy trzej spotkali się także z biskupem pińskim Kazimierzem Bukrabą. Gdy biskup usłyszał, że plan budowy kościoła jest jeszcze nie wykonany, polecił wstrzymać się z budową do czasu jego wykonania izatwierdzenia.Wmiędzyczasiezaleciłgromadzićśrodkipieniężneimateriałbudowlany. Inżynier Kukulski zobowiązał się wykonać plany do wiosny 1935 roku. W czasie spotkania z przedstawicielami Komitetu Kukulski zaproponował pewne zmiany w planach, np. rezygnację z budowy podziemi - krypty, co miało zmniejszyć w pewnym stopniu koszty budowy. Ponadto oglądając rycinę kościoła i sporządzoną odezwę zbiórkową na rzecz jego budowy wydaną przez Komitet, Kukulski zaprzeczył jakoby to był jego projekt, twierdząc że jest to raczej projekt jego kolegi ${ }^{62}$. W odpowiedzi na powyższe, gen Grzmot-Skotnicki wyraził na zebraniu Komitetu w styczniu 1935 roku wielkie zdziwienie, z wynurzeń architekta Kukulskiego, dotyczących projektu kościoła. Sprawa ta była za życia biskupa Łozińskiego szczegółowo omówiona i ustalona między nim a architektem Kukulskim, w obecności gen. Grzmot-Skotnickiego. Nie rozumiał także obecny zastępca prezesa Komitetu

${ }^{61}$ ADD, Zespół Archiwum Parafii Baranowicze, Sygn. III/W, Jan Kukulski do Komitetu Budowy Kościoła, Warszawa 29 VII 1934 (L. 1/34).

${ }^{62}$ Tamże. 
generał Grzmot-Skotnicki reakcji Kukulskiego na rycinę kościoła zamieszczoną na odezwie zbiórkowej. Swego czasu architekt Kukulski otrzymał już odezwę z zamieszczoną ryciną kościoła i wówczas żadnych zastrzeżeń nie zgłosił, a powinien to był uczynić już wówczas ${ }^{63}$.

W pobliżu placu kościelnego budowany był dom dla emerytowanego pułkownika Henryka Ossowskiego, zamieszkałego w Baranowiczach przy ul. Traugutta 17. Zdaniem prezesa ks. Borysiuka w późniejszym czasie miała się mieścić w tym domu kancelaria parafialna, a pułkownik Osowski miał rzekomo nadzorować budowę kościoła. W tej sprawie zwracał się pułkownik Osowski do prezesa ks. Borysiuka, który oświadczył mu w odpowiedzi, że uregulowanie tej kwestii zależy od decyzji Komitetu. W pewnym momencie pułkownik Ossowski przesunął płot ogradzający jego przyszłą posesję z placem kościelnym na swoją korzyść. Zdaniem Komitetu o nadzorowaniu przez pułkownika Ossowskiego budowy kościoła nie mogło być mowy, jak również o budowie domu na placu kościelnym, gdyż po jego ukończeniu trudno będzie tą inwestycję zlikwidować. Uchwałą Komitetu zdecydowano powiadomić zainteresowanego o przerwaniu budowy domu i usunięciu jego z placu w terminie 14-dniowym. Ostatecznie sprawa została załatwiona pomyślnie dla przyszłej parafii, a budowa domu w tym miejscu została zaniechana ${ }^{64}$.

Po ośmiu miesiącach od powołania nowego zarządu Komitetu (kwiecień 1934 rok), zdaniem jego członków, budowa kościoła nie postępowała, jak to wynika chociażby ze sprawozdania kasowego. Ponadto dochody Komitetu w ostatnim czasie były bardzo szczupłe. Większą skuteczność w pozyskiwaniu funduszy wykazały inne instytucje np. L.O.P.P. ${ }^{65}$, Czerwony Krzyż, dlatego też zapropo-

${ }^{63}$ ADD, Zespół Archiwum Parafii Baranowicze, Sygn. III/W, Protokół zebrania Komitetu z 28 I 1935 roku.

${ }^{64}$ Prawie cztery lata później - na początku listopada 1938 roku pułkownik Ossowski skierował do Komitetu Budowy pismo w którym stwierdzał, że w czasie budowy domu na placu kościelnym w roku 1934/1935 pozostawił w szopie materiały i narzędzia, a te poprzedni proboszcz ks. Lucjan Żołądkowski samowolnie zużył bez jego wiedzy na inne cele. Po sporządzeniu szczegółowego wykazu w dziesięciu pozycjach, wartość utraconego mienia opiewała na kwotę 666.00 złotych, której zwrotu się domagał. Na poparcie swoich roszczeń dodał, że na powyższe przedmioty pozostawione w szopie posiada pokwitowanie wydane przez dziekana ks. Jana Borysiuka. Niestety nie znamy finału załatwienia tej spray. ADD, Zespół Archiwum Parafii Baranowicze, Sygn. III/W, Protokół zebrania Komitetu z 28 I 1935 roku.

${ }^{65}$ Liga Obrony Powietrznej i Przeciwgazowej (LOPP) - paramilitarna polska organizacja powstała w 1928 roku z połączenia Towarzystwa Obrony Przeciwgazowej i Ligi Obrony Powietrznej Państwa. Celem jej było przygotowanie społeczeństwa do obrony przed nieprzyjacielskim lotnictwem i bronią chemiczną. Stąd Liga posiadała dobrze rozbudowane lotnictwo, kształciła lotników za granicą na następnie w otwartej w Radomiu szkole pilotów i mechaników samolotowych, promowała sport lotniczy, badania i rozwój konstrukcji lotniczych oraz zabiegała o wypracowanie w społeczeństwie zrozumienia i poparcia dla rozwoju lotnictwa. Dalej propagowała wśród młodzieży sportowe związki lotnicze, zwane aeroklubami, popierała rodzimy przemysł chemiczny dostarczający polskiej armii odpowiednie środki oraz uświadamiała społeczeństwo przed powietrznymi zagrożeniami chemicznym. Te działania Ligi miały wychowywać głównie młodzież szkolną w poczuciu praw i obowiązków obywatelskich. LOPP liczyła 1,5 miliona członków zrzeszonych w 14000 ko- 
nowano rozwinąć propagandę mającą na celu zjednanie stałych członków, którzy uiszczaliby składki miesięczne. Mówić o tym mieli z ambon duszpasterze kościoła parafialnego i garnizonowego. W tym celu powinny być sporządzone listy nowych członków. Miały być one wyłożone w zakrystiach kościołów w niedziele i święta. Należało także rozszerzyć działalność Komitetu na zewnątrz i zwrócić się o pomoc do odpowiednich czynników w Warszawie. Zgodził się tym zająć gen. Grzmot-Skotnicki. Zaproponowano także wysłanie odezwy do towarzystw i instytucji z prośbą o opodatkowanie się tychże przy urządzaniu imprez dochodowych na rzecz budowy kościoła. W końcu zaproponowano utworzenie w łonie Komitetu sekcji finansowej, której zadaniem byłoby zbieranie funduszy, a na wniosek prezesa wybrano członków sekcji finansowej: ks. Antoni Aleksandrowicz z kościoła garnizonowego, naczelnik Teodor Szpakowski, dyrektor Aleksander Rzepecki i dyrektor Kazimierz Weber ${ }^{66}$.

W sprawie zjednywania stałych członków Komitetu nowy jego prezes ks. Jan Borysiuk w ciągu 11 miesięcy swego urzędowania przyjął na listę 78 stałych członków, a ksiądz kapelan Aleksandrowicz ok. 30. W związku z pozyskiwaniem stałych członków Komitetu, na zebraniu dnia 12 III 1935 roku Teodor Szpakowski wnioskował, aby zaangażować inkasenta do zbierania składek członkowskich i ofiar za wynagrodzeniem nie przekraczającym $15 \%$ zainkasowanych kwot. Wniosek przyjęto. Dyrektor Adam Haleczko zaproponował przesłanie do wszystkich urzędów bloczków z prośbą, aby zainkasowane kwoty przesyłano wprost do skarbnika Komitetu. Ponadto na zebraniu starosta powiatu baranowickiego Neugebauer proponował wysłać dobrze umotywowane podanie o subwencję do Ministra WRiOP oraz do ministra Spraw Wojskowych, przez miejscowe dowództwo garnizonu wojskowego. W celu zaapelowania do ofiarności społeczeństwa na rzecz budowy kościoła postanowiono zwołać walne zebranie członków Komitetu w kinie Apollo na dzień 31 III 1935 roku $^{67}$.

Większość wydatków przeznaczano na zakup materiałów: cegły i kamienia. Znaczne kwoty pochłonęła robocizna i opłata stróża. Na dostawę cegły ogłoszono przetarg, który jednak nie doszedł do skutku, gdyż zgłoszono tylko dwie oferty. W rezultacie tego Komitet postanowił zakupić cegłę z wolnej ręki od pana Plate-

łach (1935). Te działania nie ograniczała wyłącznie do profilaktyki na wypadek wojny. Propagowała w społeczeństwie polskim pokój i dążyła do jego utrwalania. W 1934 roku Rada Ministrów uznała LOPP za stowarzyszenie wyższej użyteczności publicznej. X. S. J., L.O.P.P. do polskiego duchowieństwa katolickiego, Warszawa 1932.

${ }^{66}$ ADD, Zespół Archiwum Parafii Baranowicze, Sygn. III/W, Protokół zebrania Komitetu z 28 I 1935 roku.

${ }^{67}$ Dotychczasowy stróż placu kościelnego Kisiel pobierał wynagrodzenie miesięczne 63,00 złote. Do Komitetu wpłynęły podania Aleksandra Abrazowskiego (ul. Dąbrowskiego 33), Tadeusza Lacha (ul. Klecka 3) i Stanisława Górskiego (ul. Jeziorna 22), którzy deklarowali się podjąć obowiązki stróża za mniejsze wynagrodzenie. Zdecydowano więc uchwałą Komitetu z 12 III 1935 roku obniżyć stróżowi Kisielowi wynagrodzenie do kwoty 40,00 złotych miesięcznie. W przypadku gdyby dotychczasowy stróż nie przyjął obniżki wynagrodzenia, wówczas zdecydowano zatrudnić stróża z pośród bezrobotnych. ADD, Zespół Archiwum Parafii Baranowicze, Sygn. III/W, Protokół zebrania z 12 III 1935 roku. 
ra - ok. 20000 sztuk i od Wydziału Sejmu Powiatowego - 50000 sztuk. Za cegłę panu Platerowi płacono po 70 zł za 1000 sztuk a Sejmowi Powiatowemu 55 zł za 1000 sztuk. Zabiegi Komitetu uzyskania dogodnych warunków kupna cegły z licytacji u hrabiego Potockiego w Krzywoszynie spełzły na niczym, ponieważ cegła sprzedawana w drodze licytacji była droższa od sprzedawanej z wolnej ręki. Poza cegłą zgromadzono $149,5 \mathrm{~m}^{3}$ kamienia ${ }^{68}$.

Powołany w kwietniu 1934 roku z woli biskupa pińskiego nowy prezes Komitetu ks. Jan Borysiuk, proboszcz parafii w Baranowiczach i dziekan był przeciwny podziałowi dotychczasowej parafii pw. Podwyższenia Krzyża Świętego, z której miała zostać wydzielona nowa parafia. Stąd za jego prezesury nie zdołano nawet zakupić notarialnie placu kościelnego. Jesienią 1936 roku biskup Kazimierz Bukraba powierzył ks. Antoniemu Kohutnickiemu ${ }^{69}$ zorganizowanie od 1 października tego roku nowej parafii w Baranowiczach, z podjęciem od wiosny 1937 rok budowy kościoła pw. Matki Bożej Królowej Korony Polskiej ${ }^{70}$. Ks. A. Kohutnicki odstąpił od pierwotnego planu organizowania parafii na placu wokół ulic Mickiewicza, Kosynierów i Kochanowskiego. W zakupionym budynku drewnianym przy ulicy Rynkowej 24, otworzył tymczasową kaplicę, przy której dnia 23 I 1937 roku bp K. Bukraba erygował parafię pw. Matki Bożej Królowej Korony Polskiej i powierzył mu pełnienie obowiązków proboszcza ${ }^{71}$. Na początek parafia liczyła ponad 3.000 wiernych. Jego następcą od maja 1938 roku został ks. Czesław Fedorowicz $^{72}$, zamieszkały przy ulicy Zielonej 5, po którym z kolei parafię tę przejął

\footnotetext{
${ }^{68}$ ADD, Zespół Archiwum Parafii Baranowicze, Sygn. III/W, Protokół zebrania z 15 IV 1934 roku.

${ }^{69}$ Ks. Kohutnicki Antoni (1887-1971) - kapłan diecezji kamienieckiej. Urodził się na Wołyniu, maturę zdał w 1907 roku w Żytomierzu, w 1909 roku wstąpił do seminarium duchownego w Żytomierzu, które ukończył w 1914 roku święceniami kapłańskimi z rąk biskupa pomocniczego Longina Żarnowieckiego. Pracował w parafii Toporyszcze, Krzemieniec, Kutkowce na Podolu (proboszcz), Czercze w dekanacie kamienieckim (proboszcz), skąd w połowie 1920 roku opuścił Podole i wyjechał do Polski. Tu pracował w diecezji kieleckiej (Rakoszyn od IV do IX 1925), w diecezji podlaskiej (Dołhobrody). W 1930 roku po ekskardynowaniu z diecezji kamienieckiej wyjechał do pracy wśród emigracji polskiej we Francji, skąd po kilku miesiącach powrócił, przenosząc się do diecezji wileńskiej. Tu pracował w parafii w Giełczynie (1931-1932), Bielicy (1932-1934), Balingródku (od 1935-kilka miesięcy), Dąbrowa. W 1936 roku przeniósł się do diecezji pińskiej. Po II wojnie światowej wyjechał na Ziemie Odzyskane, gdzie od 1 IX 1945 do 15 XII 1959 roku był proboszczem parafii Łęgowo w diecezji gdańskiej. Zmarł 27 IV 1971 roku na terenie tej diecezji. Catalogus ecclesiarum et cleri Archidioecesis Vilnensis. Pro Anno Domini 1933-1936, Vilnae 1933-1936; W. Rosowski, Dzieje rzymskokatolickiej diecezji kamienieckiej w latach 1918-1941, Lublin 2008, s. 160.

${ }^{70}$ Po zatwierdzenie projektu kościoła architekt Jan Kukulski zwrócił się w listopadzie 1937 roku do prezesa Komitetu ks. Antoniego Kohutnickiego o wypłacenie mu reszty należności z tego tytułu, w kwocie 900 złotych. ADD, Zespół Archiwum Parafii Baranowicze, Sygn. III/W, Jan Kukulski do prezesa Komitetu Budowy Kościoła z 19 XI 1937 roku.

${ }^{71}$ ADD, Zespół Archiwum Parafii Baranowicze, Sygn. III/J/), Biskup Piński Kazimierz Bukraba do ks. Antoniego Kohutnickiego z 22 I 1937 (Num. 305/37), Wikariusz Generalny (sufragan Karol Niemira) do ks. A. Kohutnickiego z 23 I 1937 (L. 306/37) - Pińsk.

${ }^{72}$ Ks. Fedorowicz (Fiedorowicz) Czesław (1891-1940) - kapłan diecezji kamienieckiej. Urodził się na Podolu, gimnazjum ukończył w Kamieńcu Podolskim, w październiku 1910 roku roz-
} 
w maju następnego roku ks. Bronisław Wieliczko ${ }^{73}$, dotychczasowy prefekt szkół powszechnych i duszpasterz tej parafii ${ }^{74}$.

słowa kluczowe: Baranowicze Poleskie, historia Kościoła na Kresach Wschodnich, katolicka parafia w Baranowiczach Poleskich

\section{BIBLIOGRAFIA}

\section{Źródła archiwalne}

Archiwum Diecezjalne w Drohiczynie - ADD

Zespół Archiwum Parafii Baranowicze

Sygnatura III/W

Sygnatura. III/ J

\section{Źródła drukowane}

Bieszanow W., Twierdza Brzeska, Warszawa 2012.

począł studia seminaryjne w Żytomierzu, a kończył w Akademii Duchownej w Petersburgu (19141917), uzyskaniem stopnia kandydata prawa kanonicznego. W Petersburgu dnia 15 VI 1917 roku przyjął święcenia kapłańskie z rąk bpa Jana Cieplaka. Ordynariusz łucko-żytomierski bp Ignacy Dubowski mianował go kapelanem szkół w Białej Cerkwii (dekanat Kijów), od 6 VIII 1918 roku był wikariuszem w Płoskirowie. W lutym 1919 roku wyjechał na Uniwersytet Lubelski dla dokończenia studiów, a po uzyskaniu tytułu magistra prawa kanonicznego powrócił na Podole. W 1920 roku mianowany został promotorem sprawiedliwości i obrońcą węzła małżeńskiego w sądzie biskupim w Kamieńcu Podolskim i dziekanem w Mohylewie Podolskim (do 1921). Następnie pracował w parafii Wójtowce, Pików, Śnitków, Brahiłów (dekanat Winnica), Gniewań. Za otwarte występowanie przeciw władzy radzieckiej, jesienią 1922 roku trafił do więzienia w Winnicy. Ponownie aresztowany w 1926 roku, skazany został dnia 18 listopada tego roku na trzy lata łagru. Karę odbywał na zesłaniu na Sołówkach. Po roku powrócił do Winnicy. Tu został ponownie oskarżony o kierowanie w parafii gniewańskiej „kontrrewolucyjną organizacją”. Wyrokiem sądu winnickiego z dnia 13 II 1929 roku otrzymał karę śmierci, zamienioną na 10 lat więzienia. Odbywał ją na Chłodnej Górze w Charkowie i Jarosławiu n. Wołgą. We września 1932 roku, w wyniku wymiany grupy 51 więźniów politycznych (w tym 18 księży), powrócił do Polski. Pracował w diecezji pińskiej jako proboszcz Starojelnii (od 1933), rektor kościołów w Łopusznej i Walówce (dekanat Nowogródek) i proboszcz w Baranowiczach. Zmarł na skutek odniesionych ran w 1940 roku we Francji. Dzwonkowski, Leksykon duchowieństwa polskiego represjonowanego w ZSRR, s. 226-227; Rosowski, Dzieje rzymskokatolickiej diecezji kamienieckiej w latach 1918-1941, s. 102, 128, 158-161, 187-188, 243-244.

${ }^{73}$ Ks. Wieliczko Bronisław - urodził się 13 XI 1903 roku w Wojdziewiczach koło Wołożyna (obecnie Białoruś). Święcenia kapłańskie otrzymał w Pińsku 15 IV 1933 roku. Jako neoprezbiter przez rok pracował w Pińsku. Od połowy maja 1939 roku i w czasie drugiej wojny światowej duszpasterzował w Baranowiczach aż do momentu ewakuacji. Dnia 25 XI 1949 roku przybył w ramach tzw. repatriacji do Polski - na Ziemie Odzyskanie. Duszpasterzował jako proboszcz w parafii Lipka Krajeńska w diecezji gorzowskiej. W. Urban, Duszpasterska siejba kapłanów-repatriantów na ziemiach odzyskanych w latach 1945-1970, Wrocław 1972, s. 111.

${ }^{74}$ Szerzej na temat dziejów tej parafii do wybuchu drugiej wojny światowej i organizacji pracy duszpasterskiej patrz: W. W. Żurek, Początki parafii Matki Bożej Królowej Korony Polskiej w Baranowiczach Poleskich na podstawie księgi inwentarzowej parafii Baranowicze z 2 maja 1938 roku, „Archiwa Biblioteki i Muzea Kościelne”, 97 (2012), s. 397-411. 
Borowski E., Noty biograficzne o zmarłych kapłanach diecezji pińskiej, Drohiczyn nad Bugiem 1982 (mps -ADD).

Borowski E., Martyrologium duchowieństwa diecezji pińskiej w latach 1939-1956, w: Martyrologium duchowieństwa polskiego 1936-1956, [B. Bejze, A. Galiński] Archidiecezjalne Wydawnictwo Łódzkie Łódź 1992, s. 97-112.

Catalogus ecclesiarum et cleri Archidioecesis Vilnensis. Pro Anno Domini 1933-1936, Vilnae 1933-1936.

Cieplewicz M., Korpus Ochrony Pogranicza, w: Historii Drugiej Rzeczypospolitej, red. A. Garlicki, Warszawa 1999.

Dominiczak H., Granica wschodnia Rzeczypospolitej Polskiej w latach 1919-1939, Warszawa 1992.

Dzwonkowski R., Leksykon duchowieństwa polskiego represjonowanego w ZSRR 19391988, Lublin 2003,

Elenchus ecclesiarum et cleri saecularis ac regularis dioecesis minscensis pro Anno Domini 1924, Mińsk 1924.

Kresowi księża harcerze od Kamieńca Podolskiego do Nowogródka. Wspomnienia, opr. H. Dąbkowski, Warszawa 1999.

X. S. J., L.O.P.P. do polskiego duchowieństwa katolickiego, Warszawa 1932.

Misiurek J., Łoziński Zygmunt, w: Encyklopedia Katolicka, t. 11, Lublin 2006, kol. 554555.

Nordberga G., Historia Karola XII, Hamburg 1745-1751.

Petrani A., Bukraba Kazimierz, w: Encyklopedia Katolicka, t. 2, Lublin 1985, kol. 11891190.

W. Rosowski W., Dzieje rzymskokatolickiej diecezji kamienieckiej w latach 1918-1941, Lublin 2008.

Stawecki P., Słownik biograficzny generałów Wojska Polskiego 1918-1939, Warszawa 1994.

Spis kościołów i duchowieństwa diecezji pińskiej w R. P. 1939, Pińsk 1939.

Urban U., Duszpasterska siejba kapłanów-repatriantów na ziemiach odzyskanych w latach 1945-1970, Wrocław 1972.

Wojciechowski K., Cmentarz katolicki w Brześciu, „Niedziela” nr 45 (737) z 4 XI 2012, s. 7.

Zagacki D., Baranowicze, „Echo Polesia”, 1 (25) 2010, s. 21-27.

Żurek W. W., Początki parafii Matki Bożej Królowej Korony Polskiej w Baranowiczach Poleskich na podstawie księgi inwentarzowej parafii Baranowicze z 2 maja 1938 roku, „Archiwa Biblioteki i Muzea Kościelne”, 97 (2012) s. 397-411.

http://laurahuta.blogspot.com/2012/02/konkurs-na-projekt-kosciola-krolowej.html (dostęp: 11.03 .2013 r.) 


\title{
THE GENESIS OF THE CONSTRUCTION OF THE ROMAN CATHOLIC CHURCH DEDICATED TO OUR LADY QUEEN OF THE POLISH CROWN IN BARANOWICZE
}

\begin{abstract}
Summary
In 1928, society of the thriving borderland city of Baranowicze Poleskie launched a commendable initiative, the aim of which was to create another pastoral centre in that city for the local faithful of the Roman Rite. Those initiatives were made with great care for the spiritual good of the local faithful. The Executive Committee of the Church Construction appointed for that purpose in Baranowicze, then renamed the Citizens' Committee of the Church Construction, did not take account of church law and practice in its structure. With a lay person being in charge, it did not receive approval of the ordinary of the Diocese of Pińsk, and thus efforts to build a church could not be carried out in accordance with expectations. It was not until 1934- when the parish priest and dean of Baranowicze, Rev. Jan Borysiuk, became the president of the Committee, that the relations with the diocesan ecclesiastical authority were normalised-that authority was the one which took decisions regarding the ongoing construction work in the new pastoral centre in Baranowicze. Long-term efforts on the creation of a new parish in that town resulted in erection - on 23 January 1937- the parish dedicated to Our Lady Queen of the Polish Crown and the appointment of its first parish priest Rev.Antoni Kohutnicki.
\end{abstract}

Keywords: Baranowicze Poleskie, the history of the Church in the Polish Eastern Borderlands, Roman Catholic parishes in Baranowicze Poleskie 